2016

\title{
Reassessing the Quality of Government in China
}

Margaret Boittin

Osgoode Hall Law School of York University, mboittin@osgoode.yorku.ca

Greg Distelhorst

Francis Fukuyama

Follow this and additional works at: http:// digitalcommons.osgoode.yorku.ca/olsrps

Part of the Law Commons

\section{Recommended Citation}

Boittin, Margaret; Distelhorst, Greg; and Fukuyama, Francis, "Reassessing the Quality of Government in China" (2016). Osgoode Legal Studies Research Paper Series. 197.

http://digitalcommons.osgoode.yorku.ca/olsrps/197 


\title{
Reassessing the Quality of Government in China
}

\author{
Margaret Boittin
}

Gregory Distelhorst

Francis Fukuyama ${ }^{1}$

March 16, 2017

How should the quality of government be measured across disparate national contexts? This study develops a new approach using an original survey of Chinese civil servants and a comparison to the United States. We surveyed over 2,500 Chinese officials on two organizational features of their bureaucracies: meritocracy and individual autonomy. They report greater meritocracy than U.S. federal employees in almost all American agencies. China's edge is smaller in autonomy. Differences between the U.S. and China diminish, but do not disappear, after adjusting for respondent demographics. The meritocracy gap is also robust to excluding the Chinese respondents most likely to be affected by social desirability biases. Our findings contrast with numerous indices of good government that rank the U.S. far above China. They highlight an opportunity to improve quality of government indices by incorporating surveys of political insiders.

Keywords: governance indices, quality of government, China, bureaucracy, authoritarian politics.

${ }^{1}$ Margaret Boittin, Assistant Professor, Osgoode Hall Law School, York University, Ignat Kaneff Building, 4700 Keele St, Toronto ON M3J 1P3, Canada. +1-416-736-5349, mboittin@osgoode.yorku.ca.

Gregory Distelhorst, Assistant Professor of Global Economics and Management, MIT Sloan School of Management, Massachusetts Institute of Technology, 77 Massachusetts Ave, Cambridge MA 02139, USA. +1-617-715-2223, gregd@mit.edu.

Francis Fukuyama, Olivier Nomellini Senior Fellow and Mosbacher Director of the Center on Democracy, Development, and Rule of Law, Freeman Spogli Institute, Stanford University, 616 Serra St, Stanford CA 94305, USA.+1-650-725-9608, f.fukuyama@stanford.edu.

The authors thank Lauren Weitzman for invaluable support in all phases of this project, as well as Johnnie Jingtian Chen and Gloria $\mathrm{Yu}$ for research assistance. This study benefited from the feedback of Peter Evans, Eli Friedman, Diana Fu, Yue Hou, Paul Light, Nicholas Manning, Reo Matsuzaki, Daniel Mattingly, Jonas Nahm, Ed Steinfeld, Jason Wu, Dingxin Zhao, Tianbiao Zhu and seminar participants at Stanford University, Brown University, and Zhejiang University. This research was conducted by The Governance Project at Stanford University, which gratefully acknowledges support from The Berggruen Institute and The Chunqiu Institute. 


\section{REASSESSING THE QUALITY OF GOVERNMENT IN CHINA}

Assessing the quality of government across different countries is a major conceptual and empirical challenge. Conceptually, it requires deciding among competing definitions of "quality government." Empirically, it means measuring features of good government in ways that are comparable across disparate national contexts. A range of quality of government indices have tackled the conceptual challenge by defining both outcomes that governments should achieve (e.g. widespread basic education) and the qualities that governments should possess (e.g. limited bureaucratic red tape).

Measuring and comparing outcomes across countries is difficult but not impossible. School enrollment statistics can be computed in both Norway and Lesotho. However, measuring and comparing the qualities of good governments presents a greater challenge. Bureaucratic processes do not create easily comparable records in the same way as economic development outcomes, and the de jure practices of bureaucracies as reflected in laws may deviate greatly from their de facto operations. To meet this challenge, quality of government indices have relied on external expert judgments about the qualities of governments. For example, the World Bank Worldwide Governance Indicator (WGI) methodology uses ratings from the Country Policy and Institutional Assessments framework in its "government effectiveness" metric. Experts are asked to rate the internal management of the public bureaucracy on a scale of "little," "weak," "modest," "moderate," and "adequate" (World Bank 2015, 43-45). The WGI and other indices using judgments of external experts provide the foundation for a great volume of cross-national 
research. Daniel Kaufmann, Aart Kraay, and Massimo Mastruzzi’s (2009) article summarizing the WGI has been cited in more than six thousand publications. ${ }^{2}$

While recognizing the value of existing quality of government indices, we argue that evaluating government qualities and processes may be improved by incorporating a new source of information: surveys of public officials. These bureaucratic insiders possess an experiencebased understanding of the bureaucracy and therefore have something unique to offer the comparative study of government. Their first-hand experiences within government agencies shed light on invisible processes and understandings that shape the efficacy of organizations.

This study focuses on two organizational features associated with high-quality government: meritocracy and individual autonomy. We then present an original survey of over 2,500 Chinese civil servants about the organizational features of their workplaces. To ensure comparability with the United States, we presented Chinese respondents with survey items from the U.S. Office of Personnel Management's own survey instrument on the quality of U.S. government agencies. Our cross-national survey approach resembles that of the World Values Survey (Inglehart, Basanez, and Moreno 1998), but to our knowledge this is the first study to use this approach to draw cross-national comparisons of public officials and their organizations.

We use this study to reassess China's place as reflected in existing quality of government indices. China has one of the world's oldest traditions of bureaucratic rule, having pioneered the use of civil service examinations and merit-based promotion as early as the Former Han Dynasty, forming the bedrock of centuries of meritocratic recruitment of officials (Elman 2000, 2013; Fukuyama 2011; Zhao 2015). Yet contemporary indices of high quality government rank China quite poorly, suggesting these traditions do not extend to the present day (Figure 1). For

\footnotetext{
${ }^{2}$ Citation data retrieved from Google Scholar on October 18, 2016.
} 
example, the World Bank WGI rank China $67^{\text {th }}$ in government effectiveness and $117^{\text {th }}$ in regulatory quality, just below Azerbaijan, Cape Verde, and Paraguay. By contrast, the United States is ranked $22^{\text {nd }}$ and $25^{\text {th }}$. We use our survey of public officials to explore whether China's low rank in existing indices accurately reflects the quality of its bureaucratic processes.

Figure 1: The United States outperforms China on existing quality of government indices

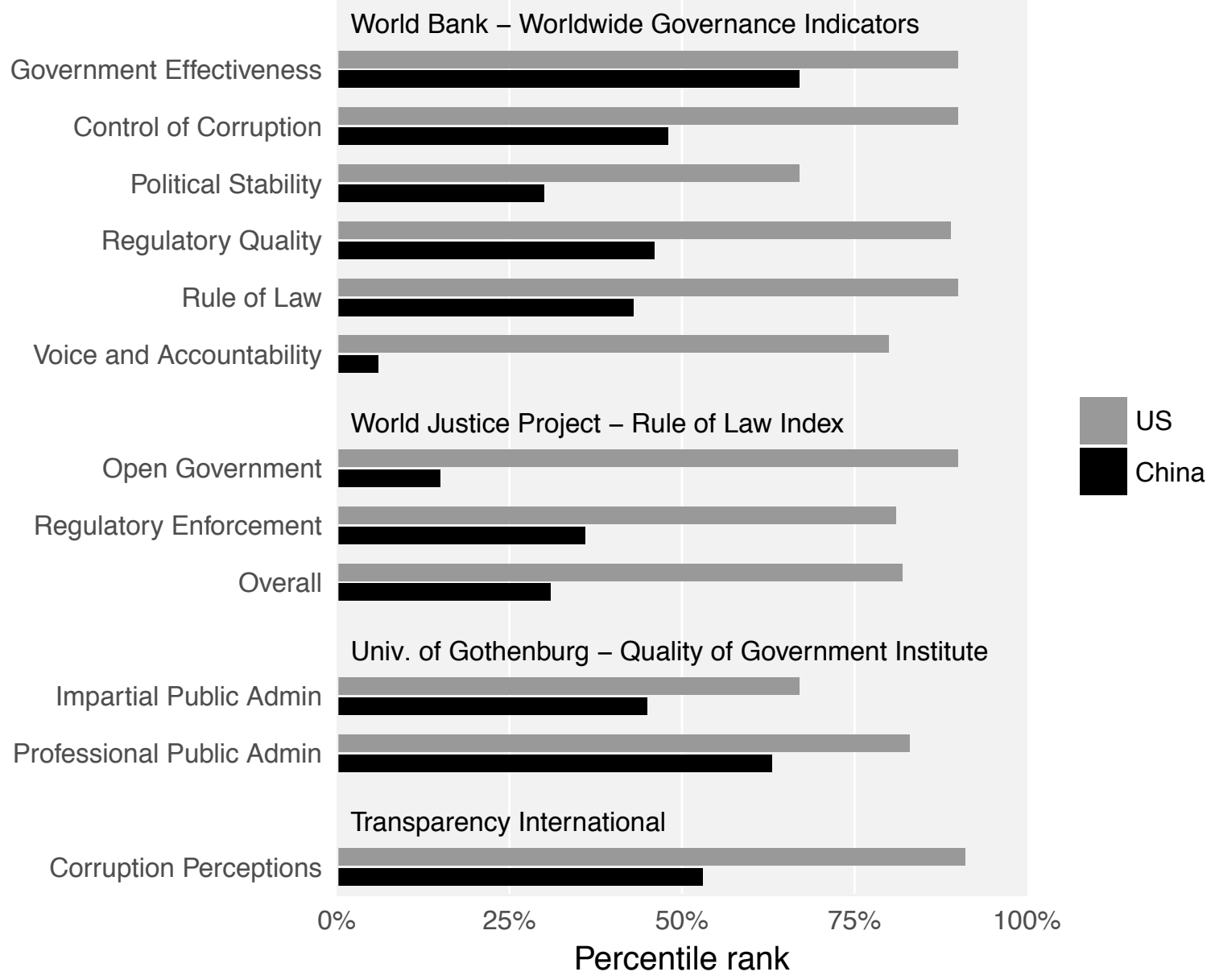

Notes. Percentile ranks ( $100 \%$ indicates top percentile, $50 \%$ indicates median) for the United States and China in selected national governance indicators in 2015 or most recently available prior year.

In examining meritocracy among mid-level bureaucrats, this study also contributes to research on the career trajectories of Chinese officials. Previous research examines career trajectories of top local officials and finds evidence of both meritocratic and factional 
considerations in promotions (Bo 2002; Landry 2008; Landry, Lü, and Duan 2015; Shih, Adolph, and Liu 2012). Local chief executives and party secretaries are important political leaders, but they comprise a small proportion of China's seven million civil servants. We offer new evidence on meritocratic recruitment and promotion of rank-and-file bureaucrats responsible for daily government activities, with comparisons to U.S. civil servants.

Finally, this study contributes to scholarship on cross-national comparison of the quality of government. ${ }^{3}$ We describe two desirable organizational features for public bureaucracies and then propose and pilot a method for measuring their presence. Our use of cross-national workplace surveys of public officials may be elaborated to measure new bureaucratic features and be expanded to new countries. Most importantly, we believe this empirical approach allows for difficult-to-observe qualities of bureaucracy to be compared across countries.

\section{MEASURING AND CONCEPTUALIZING QUALITY OF GOVERNMENT}

Numerous indices compare the quality of government across countries. These include the World Bank's WGI, Transparency International's Corruption Perception Index, the World Justice Project's Rule of Law Index, and the Quality of Government Institute's Expert Survey. ${ }^{4}$ Valuable as these indices are, they have been criticized on several points (Andrews 2010; Fukuyama 2013; Kurtz and Schrank 2007; Thomas 2010). Many provide country-year point

\footnotetext{
3 The concepts "quality of government" and "governance" are contested. For a discussion of these concepts and alternative approaches to measuring them, see Fukuyama $(2013,2016)$. ${ }^{4}$ World Bank WGI: http://info.worldbank.org/governance/wgi/index.aspx\#home. Transparency International Corruption Perceptions Index: http://www.transparency.org/research/cpi/overview. World Justice Project Rule of Law Index: http://worldjusticeproject.org/rule-of-law-index. Quality of Government Institute Expert Survey: http://qog.pol.gu.se/data/datadownloads/qogexpertsurveydata. We have excluded indices that focus on democratic development, such as the Varieties of Democracy Project (https://www.vdem.net/en/) and Freedom House (https://freedomhouse.org/).
} 
estimates in which a single number represents the aggregated performance of an entire country for a particular dimension. Such distillation does not recognize how the quality of government varies within countries, between sectors and ministries, across geographical regions, and according to level of government (i.e., national, provincial, or local) (Gingerich 2013). Second, there is disagreement about what these indices should measure. When evaluating the performance of a public school system, for example, it is possible to measure government inputs (e.g., number of teachers hired, school budgets, computers in the classroom), outputs (number of schools actually built, children matriculated), or outcomes (student performance on standardized tests, downstream earnings). There is no consensus within academic and policy circles on which aspects of state quality upon which to focus.

Even when measuring outcomes, it remains unclear how to relate these outcomes back to the quality of government. For example, China has been a poor performer in environmental protection and food safety outcomes (Economy 2004; Li and Zhou 2015; Yasuda 2015). Yet this may be the result of deliberate policy choices to privilege economic growth over the environment or food safety. Folding such policy choices into the definition of state quality prevents investigation of how state quality relates to these outcomes. The policies that a government pursues cannot simultaneously comprise the definition of good government and be the result of good government.

Finally, existing quality of government measures rely heavily on surveys that ask scholars and regional experts to evaluate government quality. In closed political systems like China's, experts have limited access to the state and must infer government quality from a combination of public sources, personal contacts, and observable outcomes. These judgments of expert observers have been shown to correlate better with announcements of government reform 
than with actual changes in government performance (Andrews 2013). This also renders such indices difficult to compare over time. Year-on-year changes in the availability of external evaluations may produce variation even when government quality is unchanged (Arndt and Romero 2008).

We propose one way to strengthen these indices is to focus on measuring the organizational features of public bureaucracies. The organizational features of bureaucracy are conceptually distinct from both the inputs to government and the outcomes of public policy. Focusing on organizational features rather than public goods outcomes does not penalize countries that either choose to spend less on certain public goods or are insufficiently productive to support high levels of public goods provision. Most importantly for our analysis of China, certain desirable features of bureaucratic organization - such as meritocracy and the autonomy and engagement of public officials - may obtain in both democratic and authoritarian regimes. These features may therefore be compared across different regime types. We therefore follow in the tradition of Peter Evans and James Rauch (1999) and Andrews (2010), both of whom compare the organizational features of public bureaucracies across countries. We extend this research by developing a new source of comparative data on these organizational structures: surveys of civil servants.

\section{Quality of Government in China}

Measuring good government and placing it in comparative context is especially challenging in China. Social scientists studying have previously shed light on many distinctive features of China's political system. These include the nomenklatura system of official appointments (Kung and Chen 2011; Shih, Adolph, and Liu 2012), "People's Congress" legislatures (Manion 2015; O’Brien 1990; Truex 2014), the "one-veto" rule in official 
performance evaluations (Birney 2014; Edin 2003), and institutions of political repression, censorship, and propaganda (Deng and O'Brien 2013; Fu 2016; King, Pan, and Roberts 2013). Although these institutions play important roles in Chinese governance, focusing on what makes China distinctive makes cross-national comparisons difficult. Recent research on rural elections and public goods (Mattingly 2016; Sun, Warner, Yang, and Liu 2013; Tsai 2007; Xu and Yao 2015) and local government responsiveness (Chen, Pan, and Xu 2015; Distelhorst and Hou 2014, 2016) offers points of departure for such comparisons. Yet even these studies were not designed to compare the quality of government in China to other countries.

Contemporary observers therefore remain divided on China's quality of government. Some maintain that meritocracy constitutes the essence of modern Chinese rule (Bell 2015; Chin 2011; Xiao and Li 2013). Others emphasize that corruption and patronage pervade the political system (Pei 2009; Rothstein 2015; Sun 2004), or that party control and factional loyalty outweigh merit in promotion criteria (Pieke 2009; Shih, Christopher, and Liu 2012).

\section{Two organizational features of bureaucracy}

We focus on measuring two "Weberian" aspects of bureaucratic organization. Weberian qualities are widely understood to underlie good public organizations. Evans and Rauch (1999, 2000) pioneered this approach in a widely-cited survey of 35 countries, and found that Weberian characteristics were highly correlated with positive development outcomes. The Quality of Government Institute's Expert Survey also uses a Weberian characteristic, impartiality, as its central measure (Rothstein 2011). The World Bank WGI also acknowledges the role of Weberian organization in the quality of government (Kaufmann, Kraay, and Mastruzzi 2009). 
Sources that comprise the WGI Government Effectiveness Index ${ }^{5}$, including the Country Performance and Institutional Assessment reports of the World Bank, African Development Bank, and Asian Development Bank, use expert judgments to measure meritocracy in bureaucratic recruitment and promotion.

Rather than elicit judgments of external experts, we collect information from public officials on two dimensions of Weberian organizations: meritocracy and individual autonomy. Meritocracy is a system of official recruitment and promotion that recognizes the primacy of talent and virtue. Meritocracy is a controversial subject, as the individual qualities that constitute "talents" and "virtues" may reasonably vary by culture, historical period, and organizational goals. We thus adopt a relatively modest definition, focusing on three features of the bureaucratic workplace. Officials should obtain their positions based on having relevant skills and abilities (meritocratic recruitment). They should advance within the bureaucracy according to those abilities and accomplishments (meritocratic promotion). Finally, because promotions are only one kind of reward for good performance, officials should also feel subjectively recognized for good performance of their duties (meritocratic recognition).

We define individual autonomy as the discretion accorded to bureaucrats in implementing their mandates and their level of engagement in decision-making and problemsolving. This definition draws on Michael Lipsky's (1983) and James Wilson's (1989) recognition of the role of discretion in public bureaucracy, scholarship on employee engagement and organizational performance (Harter, Schmidt, and Hayes 2002), and the administrative law literature on the role of administrative discretion (Mashaw, Merrill, Shane, Magill, Cuellar, and

\footnotetext{
${ }^{5}$ The sources of each WGI component can be found at: http://info.worldbank.org/governance/wgi/index.aspx\#doc (Accessed November 20, 2016)
} 
Parrillo 2014, pp. 755-760). ${ }^{6}$ Although bureaucracy requires adherence to laws and regulations, overly rigid work practices may limit the efficacy of public bureaucracies by discouraging the use of professional knowledge, creativity, and human considerations in the discharge of official duties (Lipsky 1983).

Individual autonomy and engagement is measured in three ways. First, we ask whether bureaucrats believe their individual talents are well-utilized in their official positions. Second, we ask to what extent bureaucrats are encouraged to innovate — applying their own creativity—in their work practices. Third, we examine whether bureaucrats have opportunities to meaningfully participate in decision-making, rather than simply following detailed rules or orders from superiors. By affording individuals the opportunity to participate in decision-making processes and apply their talents to achieving organizational goals, public organizations may increase employee effort and benefit from the application of local know-how.

Meritocracy and autonomy do not exhaust the desirable qualities of a public bureaucracy. Nor do they fully capture the complex "production function" of public sector agencies, which includes many external factors that are not under agency control (Manning and Shepherd 2016). However, the desirability of these two features is relatively uncontroversial. World Bank recommendations to developing countries on motivating and incentivizing civil servants include the adoption of "merit-based recruitment and promotion." (World Bank 1997, 81). Although some may advocate going beyond these Weberian features to measure organizational practices

\footnotetext{
${ }^{6}$ Our focus is on individual autonomy rather than the organizational autonomy highlighted by Evans' (1995) model of the developmental state or Daniel Carpenter's (2001) study of American political development. We do not contest the importance of these forms of bureaucratic autonomy; these features could plausibly be added to the bureaucratic organization approach to comparing quality of government.
} 
associated with the New Public Management (Hood 1995), there remains considerable disagreement over the extent to which such practices are appropriate in the institutional and economic context of the developing world (Hughes 2012).

This approach focuses on the organizational features of public institutions, not the mandates that these bureaucracies seek to implement. We avoid such normative issues not because they are unimportant, but because we aim to provide information about quality of government that is independent of these policy choices. By clearly separating the organizational features of public institutions from the normative objectives associated with democracy and human rights, we can address issues such as the degree to which state quality affects these and other development outcomes.

\section{STUDY DESIGN AND IMPLEMENTATION}

In contrast to the WGI and other quality of government indices, we attempt to measure these features through surveys of civil servants rather than judgments of external experts. The perceptions of bureaucrats have desirable features in the evaluation of the organizational features of bureaucracy. First, impressions formed through years of experience may offer unique insights into bureaucratic practices. Like any workplace, bureaucratic agencies observe many informal practices that may not appear in formal rules or organizational structure. The individuals most intimately acquainted with these practices are bureaucrats themselves. The formal credentials of officials, such as their educational degrees, may obscure less observable dimensions of merit (or lack thereof) that are apparent to individuals within the organization. Similarly, formal institutions that appear to incentivize creative problem-solving may not be effective in practice. Consider the many workplaces where soliciting suggestions or holding award ceremonies for innovation are largely ritualistic rather than effective. Divergence between formal rules and 
informal practices may be particularly widespread in the bureaucracies of developing countries. On paper, their formal systems frequently resemble those of developed countries. Yet informality remains the norm in practice: "[m]erit-based personnel rules are circumvented, and staff are recruited or promoted on the basis of patronage and clientelism" (World Bank 1997).

Despite these advantages to learning about bureaucratic organization from political insiders, there are also limitations to this empirical approach. Survey respondents may exhibit social desirability biases when reporting conditions in their own workplaces. Even in surveys where respondents are assured anonymity, the social expectation that they will provide positive evaluations of their work environments may shape responses. As elaborated below, we believe our survey items are unlikely to activate strong social desirability biases among our respondents in China. However, we also empirically explore the possibility that social desirability biases explain our results by analyzing subgroups of the Chinese respondents least likely to exhibit positive biases, as summarized in the results section.

Surveying public officials in China is challenging. There are no public registries of civil servants that allow researchers to establish sample frames. Even if researchers could obtain a sampling frame, official agencies have little political incentive to provide access to researchers, especially as government agencies have grown more circumspect under a nationwide anticorruption campaign initiated in 2012. To gain entrée into our data collection sites, we therefore relied on personal connections between Chinese academics and political elites.

We fielded our survey of civil servants in four prefectures, located in southeastern (SE), southwestern (SW), northwestern (NW), and East Central (EC) China. ${ }^{7}$ These prefectures were

\footnotetext{
${ }^{7}$ In China, prefectures are the administrative jurisdictions that make up provinces. Prefectures are composed of subordinate urban districts, counties, and various minority autonomous regions.
} 
selected through the personal connections of our survey research partners in China. We might expect that only exceptionally well-run and successful prefectures would volunteer to participate in such a study, but the four prefectures in our study are quite ordinary. They rank in the third, fourth, fifth, and seventh deciles in per capita economic output. In Appendix A, we plot nationwide decile ranks for 23 demographic, economic, and public goods indicators and find them nearly uniformly distributed between the second and eighth deciles, with few features appearing in either tail of the distribution. This suggests that surveyed prefectures were relatively ordinary and more likely to be informative of national means than surveys conducted in China's provincial capitals, which overwhelmingly occupy the top deciles in population, economic development, and public goods.

In the absence of authoritative sampling frames, we used a quota-sampling method in which we attempted to obtain responses from at least 400 civil servants at or above the rank of deputy section chief $(f u k e j i)$ at each site. ${ }^{8}$ In collaboration with the survey implementation partner, local contacts arranged for survey participants to complete written surveys under supervision of survey organization staff. Table 2 provides descriptive statistics on the sample and each of the research sites. Respondents were largely men (73\%) and overwhelmingly members of the Communist Party (90\%), consistent with research showing that party membership is an important precondition to advancing in the bureaucracy (Dickson 2014).

Most (71\%) worked in administrative agencies, $11 \%$ worked in legal institutions (sifa jiguan), and another $17 \%$ worked in legislative institutions like the People's Congress (PC) or

We anonymize the prefectures sampled in our study to protect the identities of survey respondents.

${ }^{8}$ This sampling approach resembles that used in the Local Governance and Public Goods Survey (Meng, Pan, and Yang 2015; Yang and Meng 2014), but we focus exclusively on prefectural (not provincial) officials and survey roughly twice the number of officials. 
Chinese People's Political Consultative Conference (CPPCC). We could not ask individual respondents which agencies they worked in: our sample included high-ranking local officials and combining rank and agency information could have compromised anonymity. Instead, we list government organizations represented in each prefecture (Table 3). Important agencies like the Prefectural Government Office, Development and Reform Commission, Discipline Inspection Committee, and CCP Organization Department appear in all four prefectures, as do People's Congresses, People's Courts, Public Security Bureaus, and Prosecutors' Offices.

Many respondents held positions of authority in the government and Party. One-fifth held the rank of deputy division chief ( $f u$ chuji) and may therefore serve as the deputy heads of prefectural agencies, such as tax, environmental protection, and housing administration bureaus. Six percent held the rank of division chief, placing them as leaders of these organizations. At the next level down, $28 \%$ held the rank of section chief and $26 \%$ were deputy section chiefs. These officials serve as directors and vice-directors of departments within the bureaus. ${ }^{9}$ Another quarter of the respondents held lower ranks.

${ }^{9}$ For example, a municipal tax bureau may have departments in charge of Policy, Tax Collection, Financial Planning, Statistics, Auditing, and Human Resources. Each department would be led by an official at the section chief rank. 
Table 2: China Officials Survey (2015-2016) Sample

\begin{tabular}{lc|cccc}
\hline \hline & Full & \multicolumn{4}{|c}{ By city } \\
& sample & EC & SE & SW & NW \\
\hline Demographics & & & & & \\
Female & $27 \%$ & $22 \%$ & $23 \%$ & $32 \%$ & $29 \%$ \\
Age (years) & 42.4 & 44.4 & 41.1 & 40.9 & 43.3 \\
Communist party member & $90 \%$ & $92 \%$ & $88 \%$ & $90 \%$ & $89 \%$ \\
Education & & & & & \\
High school and below & $0 \%$ & $0 \%$ & $1 \%$ & $0 \%$ & $0 \%$ \\
Vocational high school & $1 \%$ & $1 \%$ & $0 \%$ & $1 \%$ & $2 \%$ \\
Vocational college & $12 \%$ & $14 \%$ & $7 \%$ & $8 \%$ & $19 \%$ \\
University graduate & $74 \%$ & $72 \%$ & $71 \%$ & $80 \%$ & $73 \%$ \\
Master's degree & $12 \%$ & $12 \%$ & $21 \%$ & $10 \%$ & $6 \%$ \\
Doctorate & $0 \%$ & $0 \%$ & $0 \%$ & $0 \%$ & $0 \%$ \\
Official rank & & & & & \\
Below Deputy Section Chief & $26 \%$ & $13 \%$ & $21 \%$ & $34 \%$ & $34 \%$ \\
Deputy Section Chief & $20 \%$ & $14 \%$ & $30 \%$ & $17 \%$ & $20 \%$ \\
Section Chief & $28 \%$ & $23 \%$ & $30 \%$ & $29 \%$ & $30 \%$ \\
Deputy Division Chief & $20 \%$ & $33 \%$ & $17 \%$ & $18 \%$ & $11 \%$ \\
Division Chief & $6 \%$ & $13 \%$ & $2 \%$ & $3 \%$ & $4 \%$ \\
Above Division Chief & $1 \%$ & $3 \%$ & $0 \%$ & $0 \%$ & $0 \%$ \\
Organization type & & & & & \\
Administrative agencies & $71 \%$ & $72 \%$ & $69 \%$ & $80 \%$ & $64 \%$ \\
Legislative (PC, CPPCC) & $17 \%$ & $21 \%$ & $14 \%$ & $15 \%$ & $19 \%$ \\
Justice (courts, prosecutor) & $11 \%$ & $7 \%$ & $18 \%$ & $5 \%$ & $17 \%$ \\
Work experience (years) & & & & & \\
Total & 21.8 & 24.4 & 20.4 & 20.0 & 22.3 \\
In current position & 8.1 & 8.5 & 7.6 & 7.0 & 9.2 \\
\hline Total respondents & 2,575 & 635 & 568 & 678 & 694 \\
\hline
\end{tabular}


Table 3: Government and Party Organizations Represented in China Officials Survey

\begin{tabular}{|c|c|}
\hline Official respondents in... & Organizations \\
\hline All four prefectures & $\begin{array}{l}\text { CCP Prefectural Committee organizations (3): } \\
\text { Discipline Inspection Committee, Organization Department, } \\
\text { Propaganda Department } \\
\text { Chinese People's Political Consultative Conference (CPPCC) } \\
\text { Development and Reform Commission } \\
\text { Health and Family Planning Commission } \\
\text { People's Congress } \\
\text { People's Courts } \\
\text { Prefectural government bureaus (10): } \\
\text { City Planning, Education, Environmental Protection, } \\
\text { Human Resources and Social Security, Public Security, State Land, } \\
\text { Tourism, Transportation, Urban Management, Water Affairs. } \\
\text { Prefectural Government Office } \\
\text { Prosecutor's Office }\end{array}$ \\
\hline Three prefectures & $\begin{array}{l}\text { All-China Federation of Trade Unions } \\
\text { CCP Prefectural Committee organizations (3): } \\
\text { Prefectural Committee Office, Committee on Politics and Law, } \\
\text { United Front Work Department. } \\
\text { Communist Youth League Committee } \\
\text { Prefectural government bureaus (10): } \\
\text { Civil Affairs, Forestry, Housing and Urban-Rural Development, } \\
\text { Industry and Commerce, Justice, Finance, Quality Inspection, } \\
\text { Safety Inspection, Science and Technology, and Statistics. } \\
\text { Women's League }\end{array}$ \\
\hline Two prefectures & $\begin{array}{l}\text { Association for Science and Technology } \\
\text { CCP Party School } \\
\text { Civil Air Defense Office } \\
\text { Commission on the Economy and Information Technology } \\
\text { Federation of Disabled Persons } \\
\text { Federation of Industry and Commerce } \\
\text { Federation of Literature and Art } \\
\text { Organization Structure Committee } \\
\text { People's Bank Local Office } \\
\text { Policy Research Office } \\
\text { Prefectural government bureaus (8): } \\
\quad \text { Agriculture, Animal Husbandry, Archives, Auditing, Food and Drug, } \\
\quad \text { Local Taxation, Press, Publication, Radio, Film, and TV, and Retired } \\
\text { Cadres } \\
\text { Red Cross of China } \\
\text { Reception Office }\end{array}$ \\
\hline One prefecture & (49 additional organizations) \\
\hline
\end{tabular}




\section{COMPARING CHINESE AND U.S. CIVIL SERVANTS}

How do China's civil servants evaluate the organizational characteristics of government agencies? And how do these evaluations compare to bureaucrats in the United States? To enable this comparison, we selected and translated survey items on meritocracy and individual autonomy from the U.S. Office of Personnel Management's Federal Employee Viewpoint Survey (FedView). ${ }^{10}$ In the words of the OPM Director in 2015, "[FedView] is a way for us to hear from our people and respond to their feedback with genuine care and leadership."11 FedView survey data underlie public administration research on job satisfaction, diversity, and leadership in the American bureaucracy (Choi and Rainey 2010; Pitts 2009; Ting 1997, Trottier, Van Wart, and Wang 2008). FedView's 2015 survey contains responses from over 421,000 U.S. civil servants. We selected six FedView survey items for inclusion in our China survey corresponding to our dimensions of inquiry: three on meritocracy, and three on autonomy (Table 4).

Before comparing the results from China and the U.S., we examine differences in the survey samples (Figure 2). We ultimately report raw differences across the two surveys, but we also use preprocessing techniques to adjust for large differences in respondent demographics. These adjustments are important if we believe that individual characteristics may bias the evaluations of civil servants. Women make up a much larger proportion of the U.S. sample (48\%) than our survey of Chinese bureaucrats (27\%). Mandated retirement ages in China's civil service result in almost no Chinese respondents over 60 years old, compared to $15 \%$ of the U.S. sample.

\footnotetext{
${ }^{10}$ For implementation details, see https://www.fedview.opm.gov/2015/.

11 “OPM Announces Rollout of 2015 Federal Employee Viewpoint Survey” URL: https://www.opm.gov/news/releases/2015/05/fevs-launch-2015-1/ (accessed Mar 15, 2017)
} 
Table 4: U.S. FedView survey items and corresponding China Officials Survey items

FedView, 2015

China Officials Survey, 2015-16

\begin{tabular}{|c|c|c|}
\hline \multicolumn{3}{|l|}{ Meritocracy } \\
\hline Recruitment & $\begin{array}{l}\text { My work unit is able to recruit } \\
\text { people with the right skills. }\end{array}$ & $\begin{array}{l}\text { 我的工作单位能够招聘到具有 } \\
\text { 合适技能的人 }\end{array}$ \\
\hline Promotion & $\begin{array}{l}\text { Promotions in my work unit are } \\
\text { based on merit. }\end{array}$ & $\begin{array}{l}\text { 我的同事的晋升是以业绩为基 } \\
\text { 础的 }\end{array}$ \\
\hline Recognition & $\begin{array}{l}\text { How satisfied are you with the } \\
\text { recognition you receive for } \\
\text { doing a good job? }\end{array}$ & $\begin{array}{l}\text { 您对自己的工作成绩能够被单 } \\
\text { 位认可满意吗? }\end{array}$ \\
\hline \multicolumn{3}{|l|}{ Autonomy } \\
\hline $\begin{array}{l}\text { Individual } \\
\text { talents }\end{array}$ & $\begin{array}{l}\text { My talents are used well in the } \\
\text { workplace. }\end{array}$ & $\begin{array}{l}\text { 我在单位能够充分发挥自己的 } \\
\text { 聪明才智 }\end{array}$ \\
\hline Innovation & $\begin{array}{l}\text { I feel encouraged to come up } \\
\text { with new and better ways of } \\
\text { doing things. }\end{array}$ & $\begin{array}{l}\text { 我提出了新的、更好的工作方 } \\
\text { 法时，会被鼓舞 }\end{array}$ \\
\hline Participation & $\begin{array}{l}\text { How satisfied are you with your } \\
\text { involvement in decisions that } \\
\text { affect your work? }\end{array}$ & $\begin{array}{l}\text { 在您单位，您对参与和自身相 } \\
\text { 关工作的决策现状满意吗? }\end{array}$ \\
\hline
\end{tabular}

Notes. Response sets for each question on a five-point Likert scale. For agreement items the response set was strongly agree, agree, neutral, disagree, and strongly disagree. For satisfaction items the response set was extremely satisfied, satisfied, neutral, dissatisfied and extremely dissatisfied.

A majority of the Chinese officials have Bachelor's degrees, whereas the U.S. sample is almost equally distributed among pre-Bachelor's, Bachelor's and Postgraduate degrees. The education level of respondents is likely correlated with both unobservable personal characteristics, such as family background, and the types of positions individuals hold in the bureaucracy. For example, individuals with higher levels of formal education are more likely to occupy positions requiring technical expertise. If those technical positions are systematically more or less meritocratic than others, this imbalance would bias our comparison. 
Officials' ranks may also influence perceptions of meritocracy and autonomy. Indeed, 54\% of supervisors in FedView agree that officials are promoted according to their work performance, compared to just $29 \%$ of non-supervisors. Sorting our Chinese sample into supervisors and nonsupervisors is difficult; the same distinctions are not used in Chinese agencies. Instead, we use their official ranks as a proxy for supervisory status. Officials at the vice-section chief $(f u k e j i)$ rank and below are treated as non-supervisors, and all officials at the rank of section chief (zheng keji) and above are treated as supervisors. Using this mapping, $73 \%$ of the Chinese respondents are supervisors, compared to just $21 \%$ of the FedView respondents.

Finally, service time may influence officials' attitudes. Long-serving bureaucrats may be a group that finds life in the bureaucracy particularly rewarding or comfortable, leading to more positive evaluations. Alternatively, years of experience may lead to an accumulation of grievances resulting in more negative evaluations. The Chinese respondents generally had longer careers in the bureaucracy than their American counterparts, with $63 \%$ having worked for at least 15 years. 
Figure 2: Civil Servant Demographics in China and U.S. (FedView) Surveys
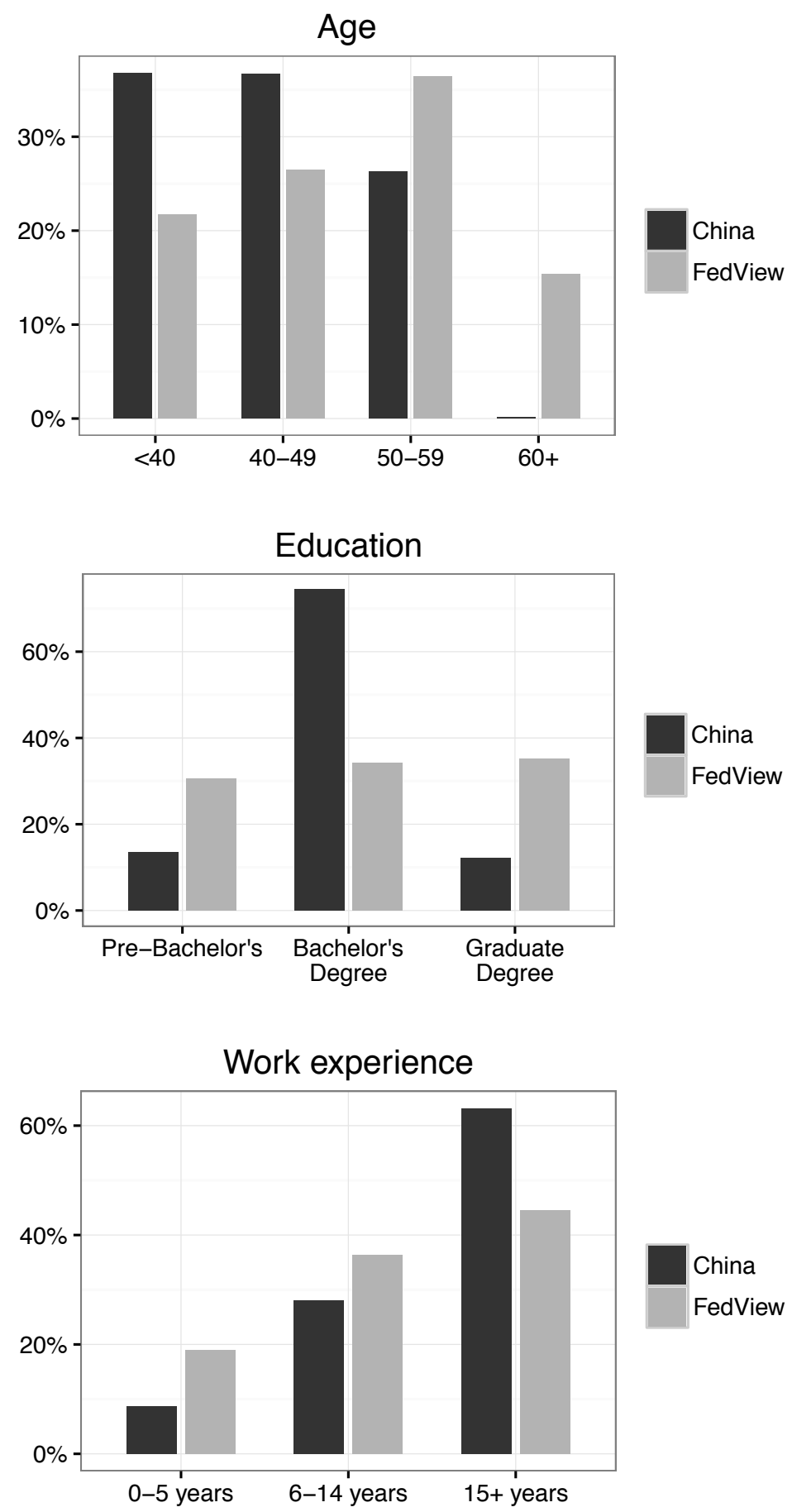

Notes. Descriptive statistics from our survey of civil servants in China and the 2015 Federal Employee Viewpoint Survey. Note that the U.S. public use data file bins these features into the groups shown in the figures. 


\section{Balancing samples on respondent characteristics}

The differences highlighted above suggest that sample composition may bias the comparison between the U.S. and China surveys. We therefore present both raw comparisons and comparisons on reweighted samples in which China and U.S. respondents exhibit similar demographic profiles on average. ${ }^{12}$

To balance the China and U.S. samples on observable characteristics, we assign new analytic weights to survey respondents using entropy balancing (Hainmueller 2012). This preprocessing technique re-weights each observation such that the moments (means, variances, and skewness) of selected variables are nearly equivalent across the two samples. Since the FedView public use data file is binned (e.g. ages in ten-year increments, rather than continuous numbers), we use each of the above categories as a binary variable in the entropy balancing process. Table 4 shows that the balancing procedure equalizes the sample means (and thus the variances and skewness, since each variable is binary) of the respondent characteristics discussed above. To ensure that our results are not idiosyncratic to this pre-processing technique, we also present comparisons using exact matching on these binary features (Blackwell, Iacus, King, and Porro 2009). Balancing on observable characteristics is not a cure-all. Even perfect balance through matching or other pre-processing techniques on observable features cannot exclude the possibility that factors other than the features of the bureaucratic workplace bias our estimates of

\footnotetext{
${ }^{12}$ Note that these adjustments may introduce some biases to the comparison of organizational features. For example, if one bureaucratic organization has higher numbers of supervisors, which results in greater autonomy, then rebalancing the samples such that they have equal numbers of supervisors would disadvantage the organization with superior autonomy. In our case, the China sample has a greater proportion of supervisors, so these adjustments may downward bias our estimates of bureaucratic autonomy in China.
} 
the differences between the Chinese and U.S. bureaucratic workplace. However, correcting for these imbalances is likely to reduce bias introduced by the differences in the two samples.

Table 4: Covariate balance in China and U.S. civil servant samples

\begin{tabular}{lcccc}
\hline \hline & \multicolumn{2}{c}{ Original samples } & \multicolumn{2}{c}{ After reweighting } \\
& China & U.S. & China & U.S. \\
\hline Female & $27 \%$ & $48 \%$ & $27 \%$ & $27 \%$ \\
Supervisor & $74 \%$ & $21 \%$ & $75 \%$ & $75 \%$ \\
Age & & & & \\
$\quad<40$ yo & $37 \%$ & $22 \%$ & $37 \%$ & $37 \%$ \\
$40-49$ & $37 \%$ & $27 \%$ & $37 \%$ & $37 \%$ \\
$50-59$ & $26 \%$ & $36 \%$ & $26 \%$ & $26 \%$ \\
$60+$ & $0 \%$ & $15 \%$ & $0 \%$ & $0 \%$ \\
Education & & & & \\
Pre-Bachelor's & $14 \%$ & $31 \%$ & $13 \%$ & $13 \%$ \\
Bachelor's Degree & $74 \%$ & $34 \%$ & $75 \%$ & $75 \%$ \\
$\quad$ Graduate degree & $12 \%$ & $35 \%$ & $12 \%$ & $12 \%$ \\
Work experience & & & & \\
0-5 years & $9 \%$ & $19 \%$ & $9 \%$ & $9 \%$ \\
6-14 years & $28 \%$ & $36 \%$ & $28 \%$ & $28 \%$ \\
15+ years & $63 \%$ & $45 \%$ & $63 \%$ & $63 \%$ \\
\hline
\end{tabular}

Notes. Samples reweighted using entropy balancing (Hainmueller 2012) on the listed variables. Each variable is a dummy $(0,1)$ binned according to the FedView 2015 public use dataset. https://www.fedview.opm.gov/2015/EVSDATA/ (accessed May 22, 2016)

Results

How do the views of Chinese officials compare to those of U.S. bureaucrats? Results in Figure 3 illustrate two patterns. First, Chinese civil servants consistently rated their workplace as superior in meritocracy and individual autonomy compared to U.S. civil servants. Second, the gap shrinks after adjusting for the observable characteristics of respondents. However, the difference remains statistically significant in every U.S-China comparison. 
Figure 3: Chinese bureaucrats report higher levels of meritocracy and autonomy

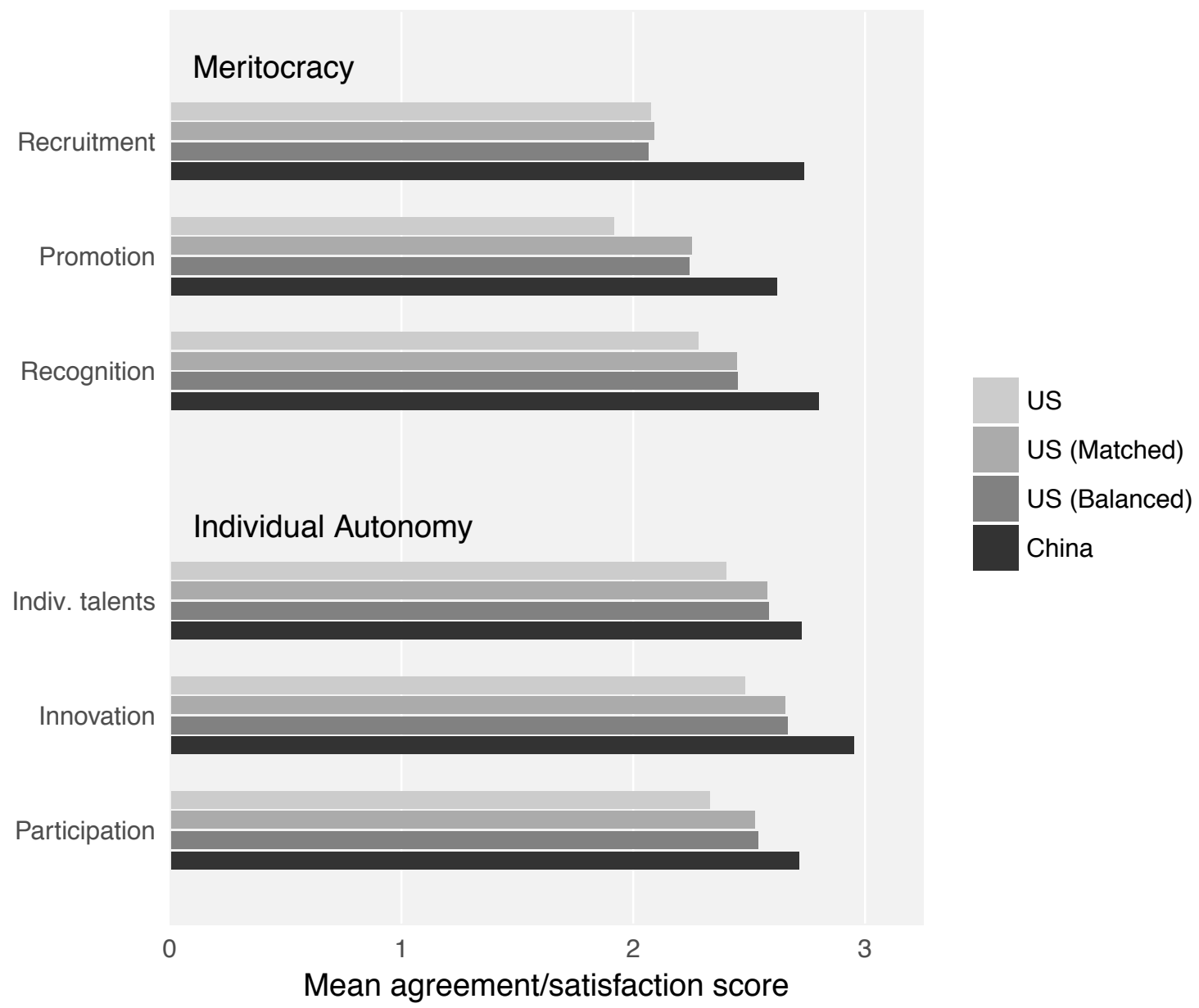

Notes. Mean responses from surveys of Chinese and U.S. civil servants (FedView). Each question offered a five-point Likert scale of agreement or satisfaction, with 0 corresponding to the most negative response and 4 corresponding to the most positive. Samples are balanced using entropy balancing (Hainmueller 2012) on respondent gender, age, supervisory status, experience in government, and education. Also shown are results after matching the samples on the same covariates using the exact matching algorithm implemented in Blackwell et al. (2009).

The substantive significance of the gap varies by item. The most dramatic difference between the two samples is in meritocratic recruitment. After balancing the samples on observables, the mean response of Chinese civil servants still exceeds that of U.S. bureaucrats by 0.63 to 0.70 units on the five-point agreement scale. On the other hand, the estimated gap for opportunities to use your talents in the workplace is relatively small, ranging from 0.09 to 0.16 units. 


\section{Addressing Social Desirability Bias Concerns}

Even after adjusting for respondent demographics, one concern is that stronger social desirability biases among Chinese officials explain the observed differences between the U.S. and China. Research on Chinese censorship suggests that the repressive apparatus is more concerned about collective action than speech that criticizes government policies and efficacy (King, Pan, and Roberts 2013), and previous survey research on public opinion in China finds that respondents are more likely to select the non-response category rather than report a biased response (Stockman 2013, 46-47). Nonetheless, it is possible that Chinese officials exhibit greater restraint in expressing criticism of government agencies, even in an anonymous survey.

One approach to dealing with social desirability biases is to use randomized survey methods such as item-count techniques or endorsement experiments. We declined to use these techniques because the U.S. FedView survey does not contain comparable survey items. Instead, we perform a series of robustness checks that exclude Chinese respondents most likely to exhibit social desirability biases. First, our main findings on meritocracy and autonomy are robust to excluding all high-ranking officials (27\% of respondents) or excluding all Communist Party members (90\% of respondents) (Appendix B, Figures B5-B6).

We then use other survey questions to identify subgroups of Chinese officials that demonstrate willingness to express socially undesirable viewpoints. We first examine only Chinese officials who express a negative view of China's signature economic achievement of the late $20^{\text {th }}$ century: economic reform and breakneck growth. They agree with the assertion that a small number of people have monopolized the benefits of Chinese reform, and that, "the vast majority of citizens have not benefited." A somewhat surprising $40 \%$ of officials agreed with 
this negative view of economic reform in China. Among them, our results for meritocracy remain, and the Chinese advantage in autonomy becomes weaker (Figure B7).

As a final robustness check, we examine the even smaller subgroup of officials $(10 \%)$ who support the right of artwork "to defame national leaders and founding fathers of China." Even among these iconoclastic respondents, China maintains its advantage in meritocratic recruitment, promotion, and recognition (Figure 4). In participation in decision-making, and using talents and knowledge, the U.S. and China are statistically indistinguishable after adjusting for respondent observable characteristics within this subgroup.

Figure 4: Robustness - Officials Permissive of Artwork Defaming China's Founding Fathers

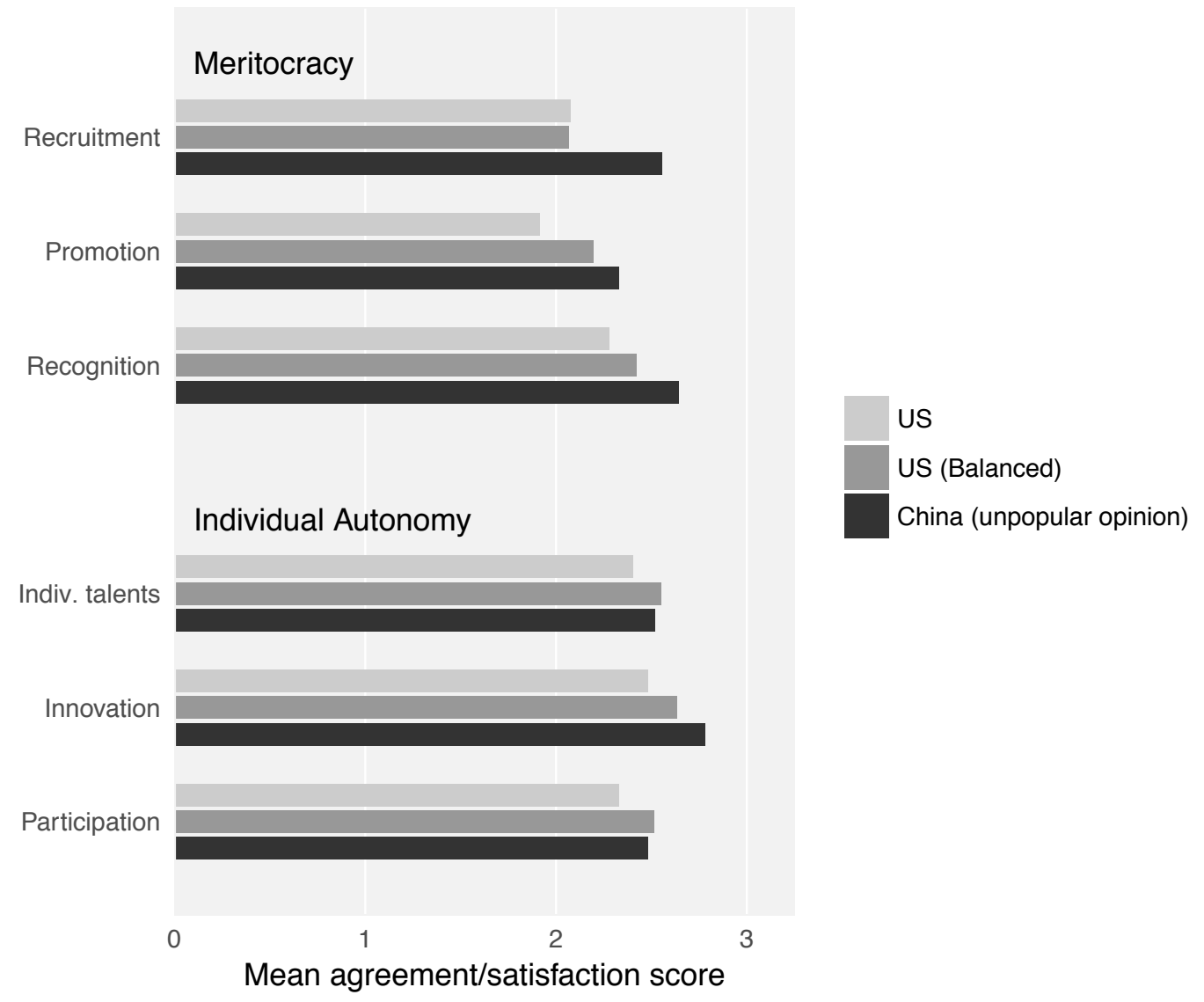

Notes. Mean responses from surveys of Chinese and U.S. (FedView) civil servants. Replication of Figure 3 examining only Chinese officials who agree that artworks may defame China's national leaders and founding fathers. China respondents in this subsample: 280. 
In summary, China's advantage in organizational meritocracy persists after removing all high-ranking officials, excluding all Chinese Communist Party members, and including only the officials for whom we have behavioral evidence of their willingness to express socially undesirable opinions. In this last subgroup, the mean level of autonomy is estimated to be at parity with the U.S. means after adjusting for respondent observable characteristics. Even within this subgroup expressing socially undesirable opinions, we detect no evidence that that they perceive lower individual autonomy than the average U.S. federal civil servant.

\section{Comparisons to U.S. Federal Agencies}

To provide greater context, we compare Chinese civil servants to civil servants in various U.S. agencies. The following figures present these comparisons for one item each from meritocracy and autonomy (for the remaining items, see Appendix B). In meritocratic recruitment, where the Chinese sample exhibits the largest advantage, none of the U.S. agencies outperform the Chinese sample (Figure 5). However, four federal agencies-the Nuclear Regulatory Commission, the Securities and Exchange Commission, the Department of Education, and the Office of Personnel Management (which implements the FedView survey)—have ratings that are statistically indistinguishable from the Chinese sample. At the bottom end, the Department of Homeland Security averages nine-tenths of a point lower on the agreement scale. However, when we examine bureaucrats' satisfaction with participation in decision-making processes - an indicator of autonomy — several agencies outperform the Chinese sample (Figure 6). The Chinese respondents fall closer to the middle of the pack. 
Figure 5: Meritocratic Recruitment in US Federal Agencies vs. China

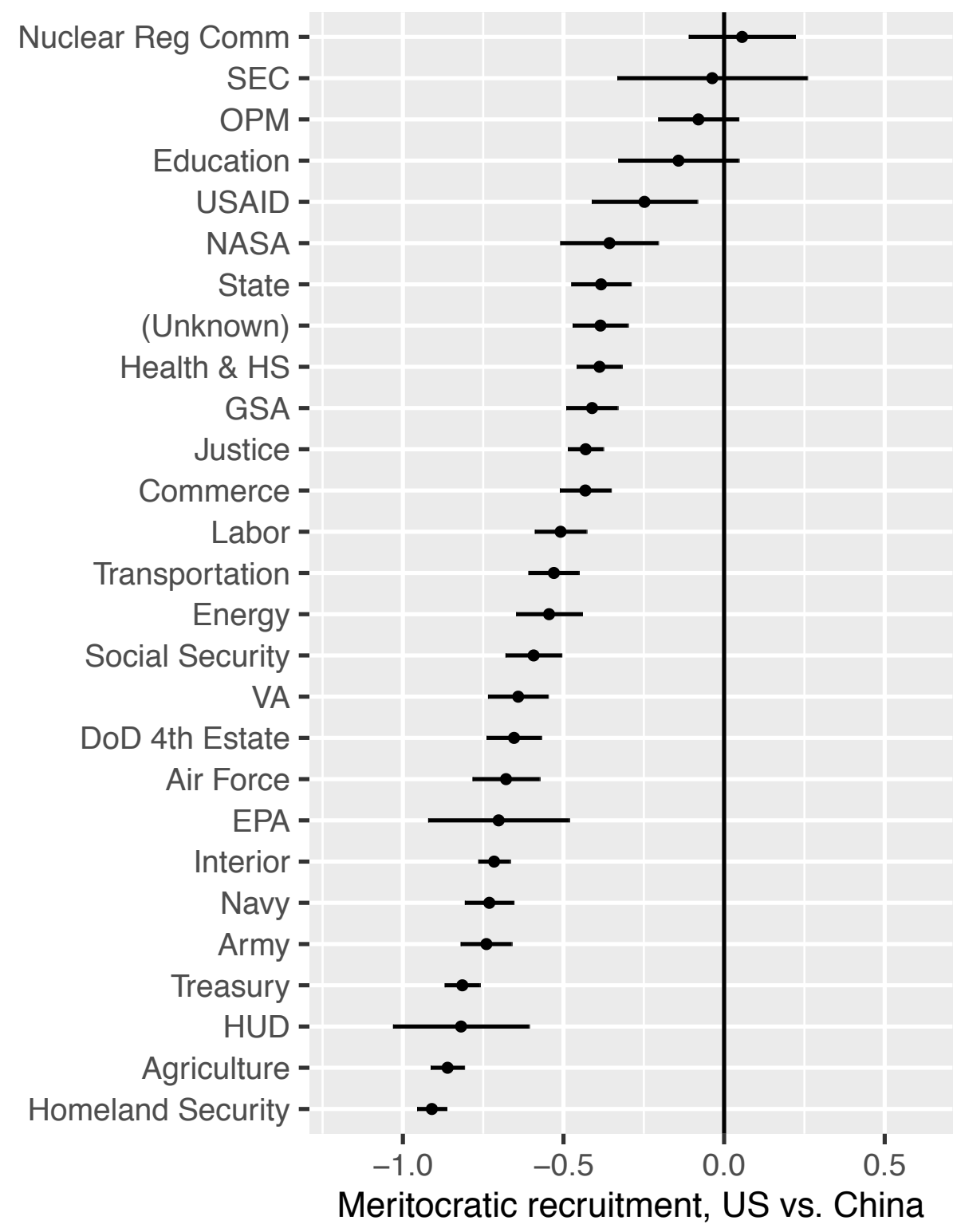

Notes. Estimated differences in mean response to meritocratic recruitment survey item in US federal agencies compared to China survey. Error bars show 95\% confidence intervals. Each federal agency subsample balanced on observables using entropy balancing. US agencies with fewer than 600 respondents not displayed. 
Figure 6: Participation in decision-making (autonomy) in US Federal Agencies vs. China

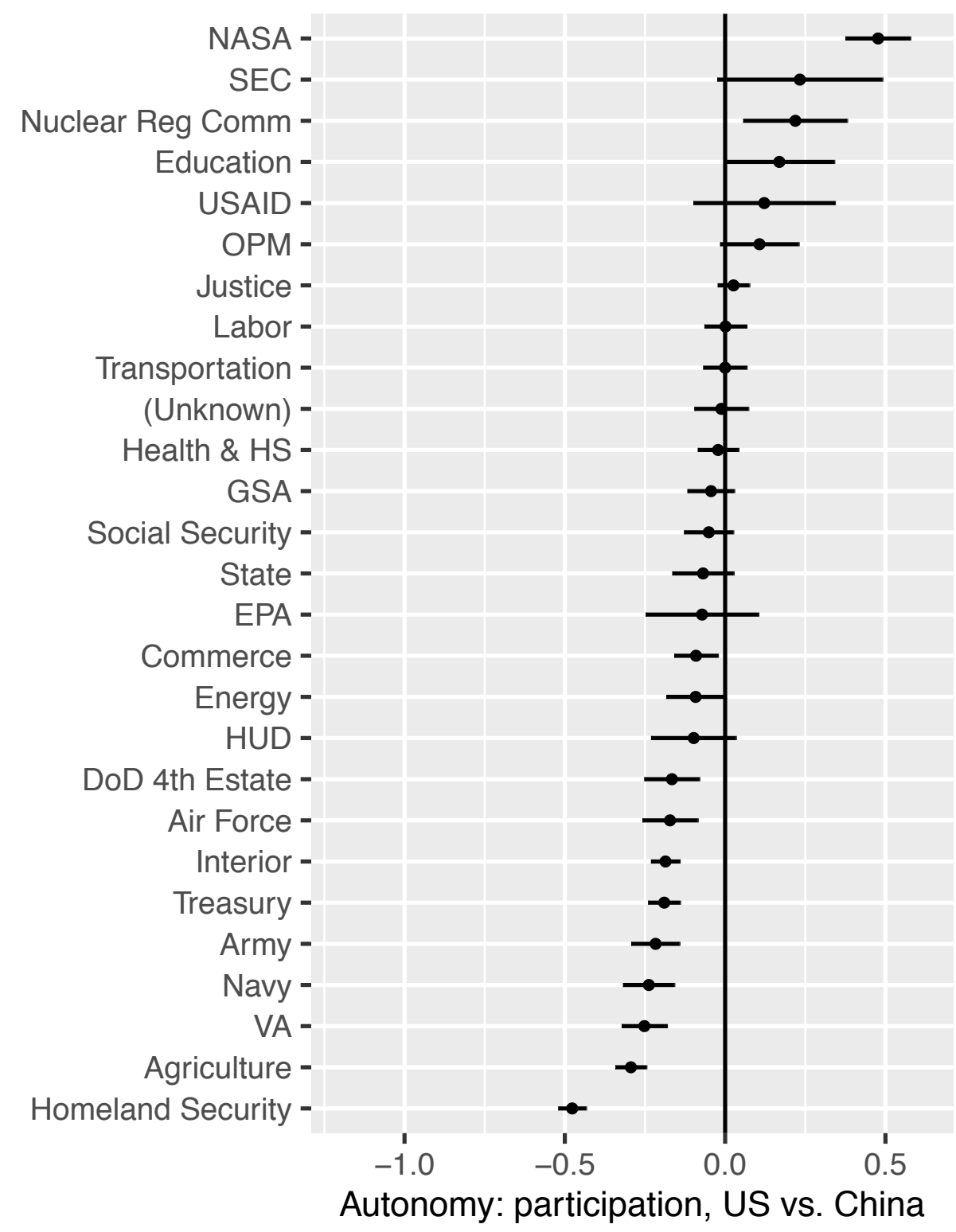

Notes. Estimated differences in mean response to participation in decision-making (autonomy battery) survey item in US federal agencies compared to China survey. Error bars show 95\% confidence intervals. Each federal agency subsample balanced on observables using entropy balancing. US agencies with fewer than 600 respondents not displayed. 


\section{CONCLUSION}

In many existing quality of government indices, such as the World Bank WGI, China is a laggard in comparison to the United States (Figure 1). The WGI indicator on government effectiveness places China at the $67^{\text {th }}$ percentile, whereas the United States is at the $90^{\text {th }}$ percentile. Yet the testimony of political insiders presented above - civil servants in the United States and Chinatells a different story. Chinese officials provide systematically higher evaluations of their public organizations surrounding both meritocracy and autonomy. The large gap in meritocracy persists after performing adjustments for demographic composition and even when examining small samples of Chinese officials that express other socially undesirable views. While the individual autonomy gap shrinks to statistical insignificance in these subgroups, we find no evidence of a U.S. advantage. However, certain U.S federal agencies achieve parity or outperform the Chinese sample.

Compared to the quality of government indices summarized in Figure 1, our main survey finding may appear unusual. Officials in a developing, authoritarian country were more likely, on average, to characterize their workplace as having Weberian qualities than officials in an advanced western democracy. Yet on further consideration this is less surprising. China's civil service is a highly sought-after profession, whereas bureaucrats are not broadly admired in American political culture. Even when China experienced a decline in civil service applicants in 2015, there were still 1.4 million candidates, or roughly 50 for each available post. ${ }^{13}$ This results in an acceptance rate lower than any Ivy League university. Such intense competition for

13 "Applications for civil service exam drop as companies beckon." The China Daily. October 28, 2015. http://www.chinadaily.com.cn/china/2015-10/28/content 22300964.htm (accessed November 23, 2016). 
Chinese civil service posts may explain why Chinese officials report their workplaces to be more meritocratic than U.S. civil servants do. The finding that Chinese officials experience greater individual autonomy and engagement can also be understood by considering the context in which bureaucrats operate across these countries. Scholars have argued that the U.S. system of separated powers breeds legalistic behavior and low autonomy as bureaucrats try to shield themselves from an adversarial political process that reaches deep into executive branch implementation (Wilson 1989). Chinese bureaucrats, by contrast, come from a tradition in which they are accustomed to governing. The high level of human capital generated by meritocratic recruitment may also enable the high levels of engagement and participation that our survey finds.

The differences between our findings and quality of government indicators that rely on expert surveys raise questions about the appropriate basis of cross-national comparisons of quality of government. Are the organizational features that support good government undervalued in expert opinions? Does a focus on government outputs - or a preference for democratic institutions - obscure the presence of high-quality organizations and processes the governments of some developing countries? This study aims to raise these questions about measuring the quality of government and to highlight the value of exploiting new sources of information to answer them.

These results also raise questions about the usefulness of summarizing a country's quality of government using a single country-year point estimate. Although the estimated mean ratings among Chinese bureaucrats are greater than the mean ratings among U.S. bureaucrats for all six indicators we examine, several U.S. federal agencies outperform the Chinese sample. Civil servants at NASA, the Nuclear Regulatory Commission, the Securities and Exchange 
Commission (SEC), and the Department of Education consistently rate their workplaces at or above the levels of our Chinese officials. The numerous respondents in Homeland Security and the Veterans' Administration (VA) drag down the mean estimates of government quality among U.S. civil servants.

There are also important limitations to this study. Political considerations in China led to non-random sampling of both jurisdictions and individuals. While the jurisdictions selected are reasonably ordinary, we have no methodological guarantee that the sample of officials we draw is statistically representative of the population. In addition, it is important to note that perceptions of meritocracy may deviate from actual practice in important ways. There is evidence that organizations perceived to be more "meritocratic" in fact exhibit higher levels of gender bias (Castilla and Benard 2010). Finally, while we perform several subgroup analyses to address the possibility that the U.S.-China gap is inflated by social desirability biases, future research may employ alternative techniques such as item-count experiments to elicit potentially socially undesirable opinions from Chinese civil servants.

We also assume that the organizational features we selected underlie good governance. Although we believe this to be true for the features we selected - meritocracy and individual autonomy - recent research questions whether Weberian bureaucracy is indeed the right recipe for countries in economic transition. Yuen Ang (2016) argues that some practices scorned by Weber, such as opportunities for officials to collect "gray income" through political connections, may support development and the successful transition to a market economy. In a similar vein, Andrews (2010) argues that even among advanced economies there is significant heterogeneity in the organizational features of good government. 
It is also important not to over-interpret the China-U.S. comparison in terms of its implications for the relative quality of the "China model" when compared to western democracy. We deliberately focused on the Weberian characteristics of government and excluded consideration of values like adherence to law, respect for individual rights, and responsiveness to citizen demands, all of which must be considered when evaluating an entire political system, rather than solely the quality of a bureaucracy. A Weberian bureaucracy can be ruthlessly efficient in censoring the media or jailing dissidents. In addition, the comparison is obviously a snapshot of two systems at a particular point in time. Had the same survey been conducted during the Cultural Revolution, when Mao sought to dismantle and demoralize the bureaucracy, China would have fared much worse. Previous generations of American bureaucrats would likely have rated themselves much more highly. Scholars of US public administration have noted that bureaucratic quality has been under increasing stress in recent decades, that the work force is aging and demoralized, and that Congress has deliberately stripped the bureaucracy of its capacity (Light 2008; Volcker 2003). None of this necessarily speaks to the long-term qualities of the political system.

The primary goal of this research is to introduce new cross-national comparative evidence on the organizational features of bureaucracy and to recommend its incorporation into quality of government indices. The organizational features that we measure through surveys of civil servants could be combined with expert characterizations of other structural variables in national governments, as pursued by Evans and Rauch (1999). To further this comparative endeavor, we hope that similar civil servant surveys will be replicated in other large, complex countries in the future. It would contribute to our knowledge of governance if researchers could standardize survey instruments across different countries, much as the US General Social Survey 
became the basis for the World Values Survey (Inglehart 1995). If such a survey can be done in a large authoritarian country like China, it could certainly be carried out in other, more open societies. 


\section{REFERENCES}

Andrews, Matt. 2010. "Good Government Means Different Things in Different Countries" Governance, 23(1): 7-35.

Andrews, Matt, 2013. The Limits of Institutional Reform: Changing Rules of Realistic Solutions (New York: Cambridge University Press).

Ang, Yuen. 2016. How China Escaped the Poverty Trap (Ithaca: Cornell University Press).

Arndt, Christiane and Carmen Romero. 2008. "Review of the policy utility of the Worldwide Governance Indicators for the Central American Countries" World Bank Working Paper Series on Public Sector Management, 08-01.

Bell, Daniel A., 2015. The China Model: Political Meritocracy and the Limits of Democracy (Princeton, NJ: Princeton University Press).

Bersch, Katherine, Sérgio Praça, and Matthew M. Taylor, 2016. "State Capacity, Bureaucratic Politicization, and Corruption in the Brazilian State" Governance, 30(1): 105-124.

Birney, Mayling. 2014. "Decentralization and veiled corruption under China's "rule of mandates"." World Development 53: 55-67.

Blackwell, Matt, Stefano Iacus, Gary King and Giuseppe Porro. 2009. "cem: Coarsened exact matching in Stata”. Stata Journal, 9(4): 524.

Bo, Zhiyue. 2002. Chinese Provincial Leaders: Economic Performance and Political Mobility since 1949. (Armonk, NY: M.E. Sharpe).

Carpenter, Daniel P., 2001. The Forging of Bureaucratic Autonomy: Reputations, Networks, and Policy Innovation in Executive Age (Princeton, NJ: Princeton University Press).

Castilla, Emilio J. and Stephen Benard. 2010. "The Paradox of Meritocracy in Organizations" Administrative Science Quarterly, 55(4), pp.543-676.

Chen, Jidong, Jennifer Pan, and Yiqing Xu. 2016. "Sources of authoritarian responsiveness: A field experiment in China" American Journal of Political Science, 60(2): 383-400.

Chin, Gregory T., 2011. "Innovation and Preservation: Remaking China's National Leadership Training System," China Quarterly 205: 18-39.

Choi, S. and Rainey, H. G. 2010. "Managing Diversity in U.S. Federal Agencies: Effects of Diversity and Diversity Management on Employee Perceptions of Organizational Performance." Public Administration Review, 70: 109-121. 
Deng, Yanhua, and Kevin J. O'Brien. 2013. "Relational repression in China: using social ties to demobilize protesters." The China Quarterly 215: 533-552.

Dickson, Bruce J., 2014. "Who Wants to Be a Communist? Career Incentives and Mobilized Loyalty in China." The China Quarterly, 217, pp.42-68.

Distelhorst, Greg, and Yue Hou. 2014. "Ingroup bias in official behavior: A national field experiment in China." Quarterly Journal of Political Science 9.2: 203-230.

Distelhorst, Greg, and Yue Hou. 2016. "Constituency Service Under Nondemocratic Rule: Evidence from China." Journal of Politics. DOI: 10.1086/690948

Economy, Elizabeth C., 2011. The river runs black: the environmental challenge to China's future. Cornell University Press.

Edin, Maria. 2003. "State Capacity and Local Agent Control in China: CCP Cadre Management from a Township Perspective" The China Quarterly, 173: 35-52.

Elman, Benjamin A., 2000. A Cultural History of Civil Examinations in Late Imperial China Berkeley, CA: Univ. of California Press.

Elman, Benjamin A., 2013. Civil Examinations and Meritocracy in Late Imperial China Cambridge, MA: Harvard University Press.

Evans, Peter B., 1995. Embedded Autonomy: States and Industrial Transformation (Princeton, NJ: Princeton University Press).

Evans, Peter B. and James E. Rauch, 1999. " Bureaucracy and Growth: A Cross-National Analysis of The Effects of 'Weberian' State Structures on Economic Growth," American Sociological Review 64(5): 748-765.

Florini, Ann, Hairong Lai and Yeling Tan. 2012. China Experiments: From Local Innovations to National Reform. Brookings.

Fu, Diana, 2016. "Fragmented Control: Governing Contentious Labor Organizations in China" Governance, forthcoming.

Fukuyama, Francis, 2011. The Origins of Political Order: From Prehuman Times to the French Revolution (New York: Farrar, Straus and Giroux).

Fukuyama, Francis, 2013. "What Is Governance?" Governance 26 (3): 347-368.

Fukuyama, Francis, 2016. "Governance: What Do We Know and How Do We Know It?" Annual Review of Political Science. 19: 89-105. 
Gingerich, Daniel W. 2013. "Governance Indicators and the Level of Analysis Problem: Empirical Findings from South America," British Journal of Political Science 43(3): 505540 .

Harter, James K., Frank L. Schmidt, and Theodore Hayes. 2002. "Business-Unit-Level Relationship Between Employee Satisfaction, Employee Engagement, and Business Outcomes: A Meta-Analysis” Journal of Applied Psychology, 87(2): 268-279.

Hood, Christopher. 1995. The "New Public Management" in the 1980s: variations on a theme. Accounting, organizations and society, 20(2), 93-109.

Hughes, Owen. 2012. Public Management and Administration: An Introduction. New York: Palgrave-MacMillan.

Inglehart, R.F., Basanez, M. and Moreno, A., 1998. Human values and beliefs. University of Michigan Press.

King, Gary, Jennifer Pan, and Margaret Roberts. 2013. "How censorship in China allows government criticism but silences collective expression" American Political Science Review, 107(02), 326-343.

Kaufmann, Daniel, Aart Kraay, and Massimo Mastruzzi. 2009. "Governance matters VIII: aggregate and individual governance indicators, 1996-2008." World Bank Policy Research Working Paper 4978.

Klitgaard, Robert, 1988. Controlling Corruption. Univ of California Press.

Kung, James Kai-sing, and Shuo Chen. 2011. "The tragedy of the nomenklatura: Career incentives and political radicalism during China's Great Leap famine." American Political Science Review 105(1): 27-45.

Kurtz, Marcus J. and Andrew Schrank. 2007. "Growth and governance: Models, measures, and mechanisms” Journal of Politics, 69(2), pp.538-554.

Landry, Pierre F., 2008. Decentralized Authoritarianism in China: The Communist Party's Control of Local Elites in the Post-Mao Era. Cambridge: Cambridge University Press.

Landry, Pierre, Xiaobo Lü, and Haiyan Duan. 2015. "Does Performance Matter? Evaluating Political Selection along the Chinese Administrative Ladder" APSA 2014 Annual Meeting Paper. http://papers.ssrn.com/sol3/papers.cfm?abstract_id=2452482.

Li, Hongbin and Li-An Zhou, 2005. "Political Turnover and Economic Performance: The Incentive Role of Personnel Control in China," Journal of Public Economics 89: 1743-62.

Light, Paul C., 2008. A Government Ill Executed: The Decline of the Federal Service and How to Reverse It (Cambridge, MA: Harvard University Press). 
Lipsky, Michael, 1983. Street-Level Bureaucracy: The Dilemmas of the Individual in Public Service. Russell Sage Foundation.

Manion, Melanie. 2015. Information for Autocrats: Representation in Chinese Local Congresses. Cambridge: Cambridge University Press.

Manning, Nicholas and Geoffrey Shepherd. 2016. "Identifying factors pertinent to public sector agency performance which could be informed by civil servant surveys: A framework for a literature review." Scoping Paper, The World Bank.

Mashaw, Jerry L., Richard A. Merrill, Peter M. Shane, M. Elizabeth Magill, Mariano-Florentino Cuellar, and Nicholas R. Parrillo, 2014. Administrative Law: The American Public Law System, cases amd materials, Seventh Edition (St. Paul, MN: West Academic Publishing).

Mattingly, Daniel. 2016. "Elite Capture: How Decentralization and Informal Institutions Weaken Property Rights in Rural China" World Politics. 68 (3): 383 - 412.

Meng, Tianguang, Jennifer Pan, and Ping Yang. 2015. "Conditional Receptivity to Citizen Participation: Evidence from a Survey Experiment in China" Comparative Political Studies

Minxin, Pei. 2009. China's trapped transition: The limits of developmental autocracy. Harvard University Press.

O'Brien, Kevin J. 1990. Reform Without Liberalization: China's National People's Congress and the Politics of Institutional Change. Cambridge: Cambridge University Press.

Pieke, Frank N., 2009. The Good Communist: Elite Training and State Building in Today's China. Cambridge: Cambridge University Press.

Pitts, D. (2009), Diversity Management, Job Satisfaction, and Performance: Evidence from U.S. Federal Agencies. Public Administration Review, 69: 328-338.

Rauch, James E. and Peter B Evans. 2000. "Bureaucratic Structure and Bureaucratic Performance in Less Developed Countries," Journal of Public Economics 75: 49-71.

Rothstein, Bo, 2011. The Quality of Government: Corruption, Social Trust, and Inequality in International Perspective (Chicago, Il: University of Chicago Press).

Rothstein, Bo, 2015. "The Chinese Paradox of High Growth and Low Quality of Government: The Cadre Organization Meets Max Weber" Governance, 28(4), pp.533-548.

Shih, Victor, Christopher Adolph, and Mingxing Liu, 2012. "Getting Ahead in the Communist Party: Explaining the Advancement of Central Committee Members in China," American Political Science Review 106(1): 166-187. 
Stockmann, Daniela. 2013. Media Commercialization and Authoritarian Rule in China. Cambridge University Press.

Sun, Yan, 2004. Corruption and Market in Contemporary China. (Ithaca, NY: Cornell University Press)

Sun, Xin, Travis Warner, Dali Yang, and Mingxing Liu, 2013. "Patterns of Authority and Governance in Rural China: Who's in Charge? Why?" Journal of Contemporary China 22(83): 733-754.

Thomas, Melissa A. 2010. "What Do the Worldwide Governance Indicators Measure?" European Journal of Development Research 22: 31-54.

Ting, Yuan 1997. "Determinants of job satisfaction of federal government employees." Public Personnel Management. 26(3): 313-334.

Trottier, T., Van Wart, M. and Wang, X. (2008), Examining the Nature and Significance of Leadership in Government Organizations. Public Administration Review, 68: 319-333.

Truex, Rory. 2014. "The returns to office in a "rubber stamp" parliament." American Political Science Review 108(2): 235-251.

Tsai, Lily L., 2007. Accountability without democracy: Solidary groups and public goods provision in rural China. Cambridge University Press.

Volcker, Paul, 2003. Revitalizing the Federal Government for the 21st Century: Report of the National Commission on the Public Service. Washington, DC.

Weber, Max, 1978. Economy and Society. Berkeley, CA: University of California Press.

Wilson, James Q., 1989. Bureaucracy (New York: Basic Books).

World Bank. 1997. World Development Report 1997 (Washington, DC: The World Bank).

World Bank. 2015. CPIA 2015 Criteria. URL:

http://pubdocs.worldbank.org/en/203511467141304327/CPIA-Criteria-2015.pdf (accessed March 15, 2017)

Xiao, Hong and Chenyang Li. 2013. "China's Meritocratic Examinations and the Ideal of Virtuous Talents," in Bell, Daniel A. and Chenyang Li, The East Asian Challenge for Democracy: Political Meritocracy in Comparative Perspective. Cambridge: Cambridge University Press.

$\mathrm{Xu}$, Yiqing and Yang Yao. 2015. "Informal institutions, collective action, and public investment in rural china" American Political Science Review, 109(02), pp.371-391. 
Reassessing the Quality of Government in China

Online Supplement

Yang, Ping and Tianguang Meng. 2014. "Exploring the Political Values of Youth Public Servants in China." China Youth Study.

Yasuda, John. 2015. "Why food safety fails in China: The politics of scale." The China Quarterly 223: 745-769.

Zhao, Dingxin. 2015. The Confucian-Legalist State: A New Theory of Chinese History. Oxford University Press. 


\section{APPENDIX A: SAMPLED PREFECTURES}

The four prefectures sampled in this study were selected according to where our local research partners could secure access to large numbers of municipal officials. We are therefore concerned that these jurisdictions may be exceptional and unrepresentative of Chinese administrative jurisdictions on the whole. To investigate this question, we computed the decile ranks of sampled prefectures among all Chinese prefectures in available economic and demographic indicators. Appearing in the tenth decile means that the prefecture lies between the $90^{\text {th }}$ and $100^{\text {th }}$ percentile for that characteristic. All data come from the 2014 Statistical Yearbook of the Regional Economy (China Statistics Press), which reports indicators for 2013. Rather than report decile ranks for each of the four prefectures, which yields statistical signatures that may permit their identification, we report the four-prefecture average decile ranks in Table A1.1 and offer brief qualitative descriptions of each prefecture below.

Southeast (SE) is a middle-income prefecture with a high proportion of private sector employers. Despite being relatively populous and export reliant, its economic output per capita is near the national median. Its economic composition is tilted toward the primary and service sectors, but industrial output is not far below the median. Although government revenue is above the median, expenditures per capita are again near the national median.

Southwest (SW) is a more industrialized prefecture on the interior with a population near the national median. Its economic output per capita is slightly below the median, and it has higher shares of primary and secondary sector economic output. Compared to the other prefectures in our sample, it has low exposure to the international economy.

Northwest (NW) is a poorer rural prefecture, ranking at the high end of the distribution of rural households and share of primary sector economic output. Industry contributes relatively 
little to economic output, and it ranks low in per capita GDP. The government collects low revenue per capita, but ranks high in expenditures per capita. Its public health resources are relatively weak, with low ranks in doctors and hospital beds per capita.

East Central (EC) is our most economically developed prefecture. It appears in the upper half of per capita economic output. It is also geographically compact with a high population density. EC is among the most industrialized prefectures in China, with a large share of secondary sector economic output.

Table A1 shows that the average rank of these four prefectures in a variety of economic and demographic features is close to the national median. Figure A1 displays the distribution of 87 decile ranks computed (five data points for surveyed prefectures were missing). We find relatively few extreme ranks in the tails. 13 indicators rank in the first or second deciles, and another six rank in the ninth or tenth deciles. The remaining 74 ranks $(85 \%)$ fall between the third decile and eighth decile of the national distribution. The average decile rank across all comparisons is 5.3, suggesting that in aggregate these four prefectures are relatively ordinary.

Comparing the four sample prefectures to well-known prefectures in China illustrates how exceptional most well-known cities in China are. Take, for example, the coastal city of Shenzhen, China's export manufacturing hub. It is one of the geographically most compact prefectures in China, and ranks in the top decile for 13 of the indicators we examine, including total GDP, per capita GDP, imports, exports, cars, mobile subscribers, and doctors. Even less well-known provincial capital cities are quite extraordinary. The capital of Hunan province, Changsha, ranks in the top decile for nine of the indicators we examine, including GDP and per capita GDP. Despite non-random selection, our sample is relatively ordinary among Chinese prefectures in terms of demographics and economics. 
Reassessing the Quality of Government in China Online Supplement

Table A1: Average decile ranks of surveyed prefectures compared to large prefectures

\begin{tabular}{|c|c|c|c|c|c|}
\hline \multirow[b]{2}{*}{ Indicator } & \multirow{2}{*}{$\begin{array}{c}\text { Four surveyed prefectures } \\
\text { Average decile rank }\end{array}$} & \multicolumn{4}{|c|}{ Reference: large prefectures } \\
\hline & & Nanjing & Changsha & Shenzhen & Urumqi \\
\hline Land area (sq km) & 4 & 3 & 5 & 1 & 6 \\
\hline Population & 6 & 10 & 9 & 10 & 6 \\
\hline Population density & 7 & 10 & 8 & 10 & 5 \\
\hline Rural households (\%) & 7 & 1 & 5 & . & 1 \\
\hline GDP & 6 & 10 & 10 & 10 & 8 \\
\hline Per capita GDP & 5 & 10 & 10 & 10 & 9 \\
\hline Primary sect. GDP (\%) & 6 & 1 & 2 & 1 & 1 \\
\hline Secondary sect. GDP (\%) & 6 & 3 & 8 & 3 & 2 \\
\hline Tertiary sect. GDP (\%) & 4 & 10 & 8 & 10 & 10 \\
\hline Private sector empl (\%) & 6 & 10 & 6 & 10 & . \\
\hline Import share of GDP & 5 & 10 & 7 & 10 & 7 \\
\hline Export share of GDP & 5 & 9 & 6 & 10 & 9 \\
\hline FDI share of GDP & 7 & 9 & 9 & 8 & 3 \\
\hline Per cap. rural disposable income & 6 & 10 & 10 & . & 8 \\
\hline Per cap. urban disposable income & 4 & 10 & 10 & 10 & 4 \\
\hline Per cap. government revenue & 5 & 10 & 10 & 10 & 10 \\
\hline Per cap. government exp. & 5 & 9 & 8 & 10 & 9 \\
\hline Highways per $\mathrm{km}^{2}$ land area & 6 & 9 & 8 & 5 & 2 \\
\hline Cars per capita & 4 & 9 & 10 & 10 & . \\
\hline Mobile subscribers per cap. & 5 & 9 & 10 & 10 & 10 \\
\hline Broadband connections per cap. & 7 & 9 & 8 & 9 & 9 \\
\hline Doctors per capita & 4 & 9 & 10 & 8 & 10 \\
\hline Hospital beds per capita & 4 & 8 & 10 & 1 & 10 \\
\hline
\end{tabular}


Figure A1 Decile ranks of surveyed prefecture economic and social characteristics

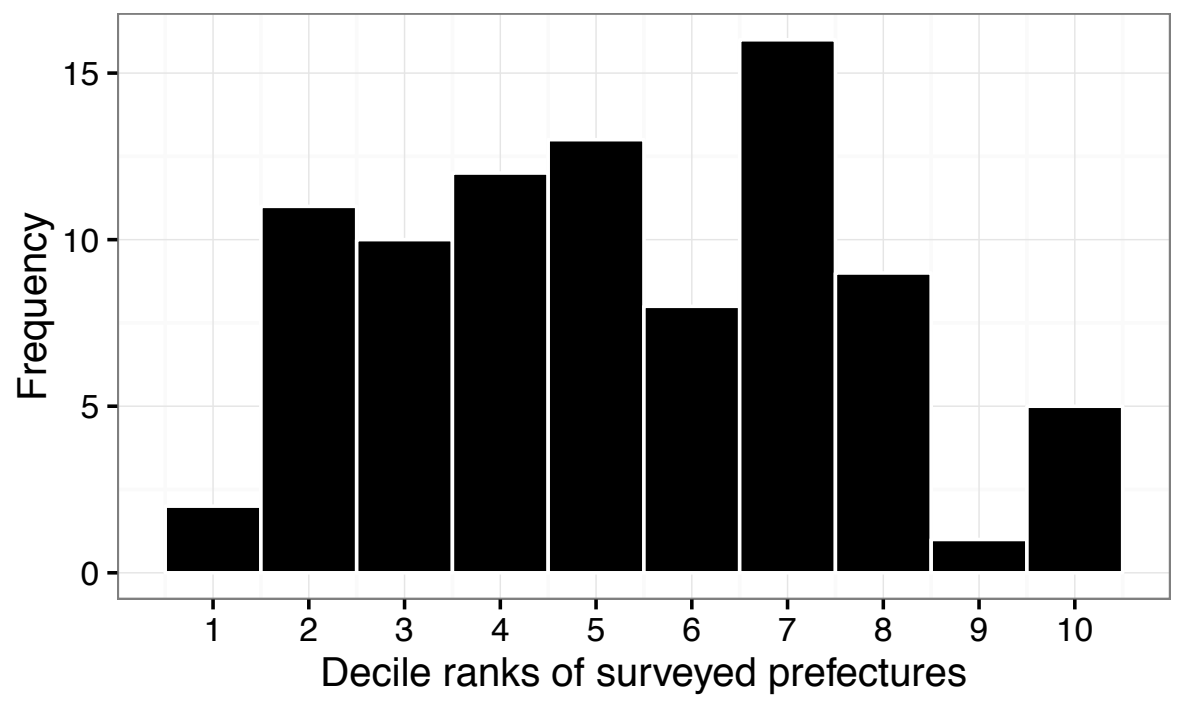

Notes. Histogram shows the distribution of decile ranks for all indicators listed in Table A1.1 for our four surveyed prefectures. 87 ranks shown in total, as five data points were missing. 


\section{APPENDIX B: ADDITIONAL FIGURES}

Figures B1-B4. Estimated differences in mean response to survey items in US federal agencies compared to China survey. Error bars show $95 \%$ confidence intervals. Each federal agency subsample is balanced on respondent observables using entropy balancing. US agencies with fewer than 600 respondents are not displayed.

Figure B1: Meritocratic promotion in US Federal Agencies vs. China

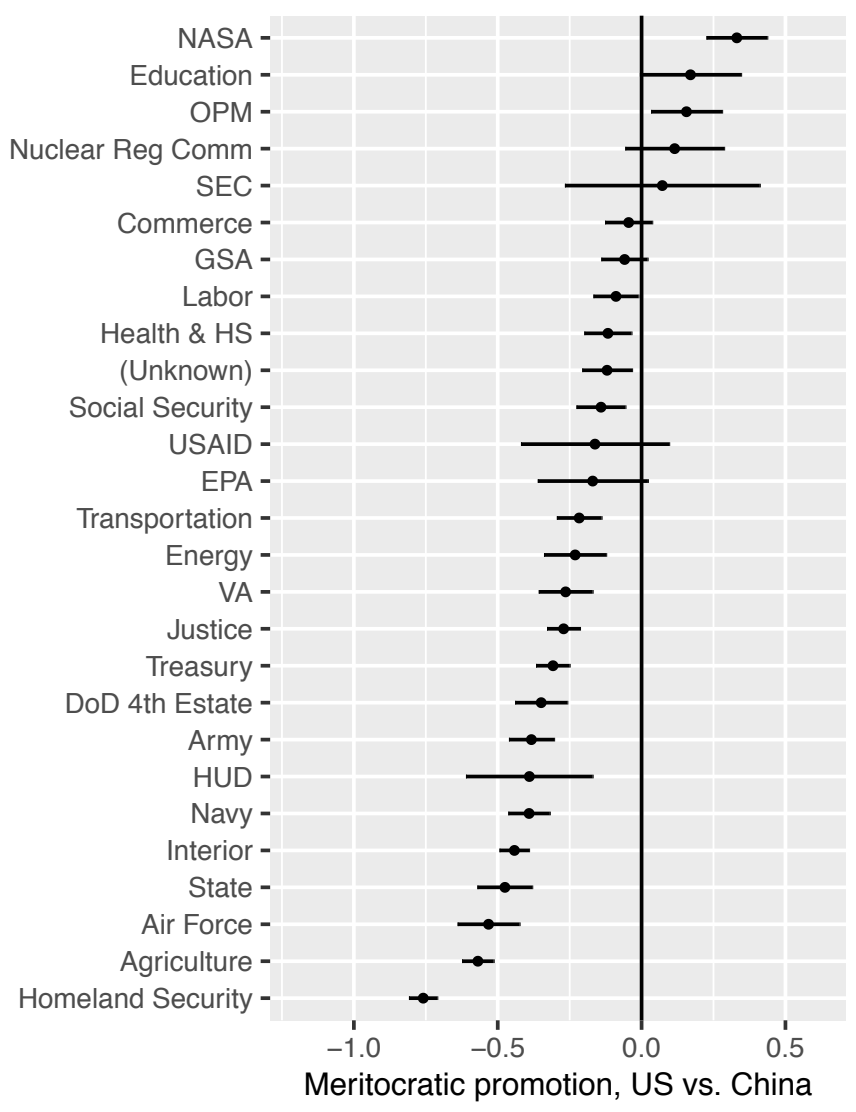

Figure B2: Meritocratic recognition in US Federal Agencies vs. China

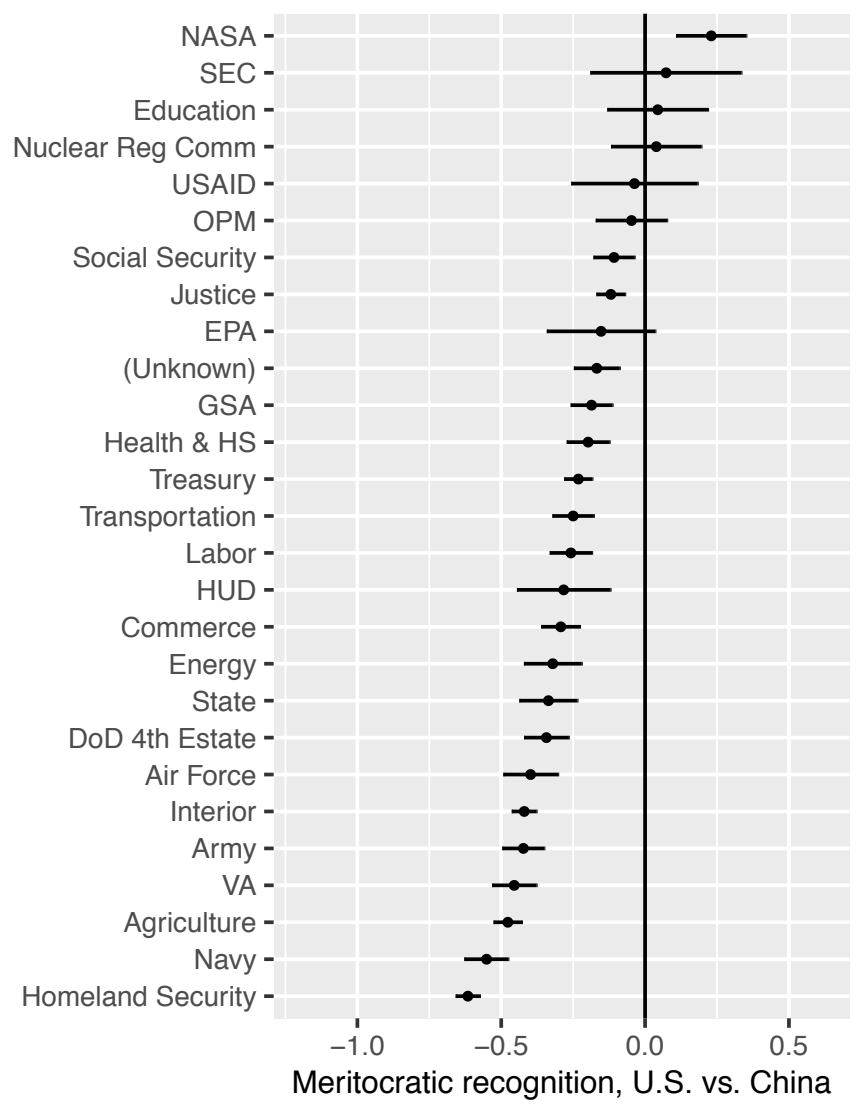


Figure B3: Use of individual talents (autonomy) in US Federal Agencies vs. China

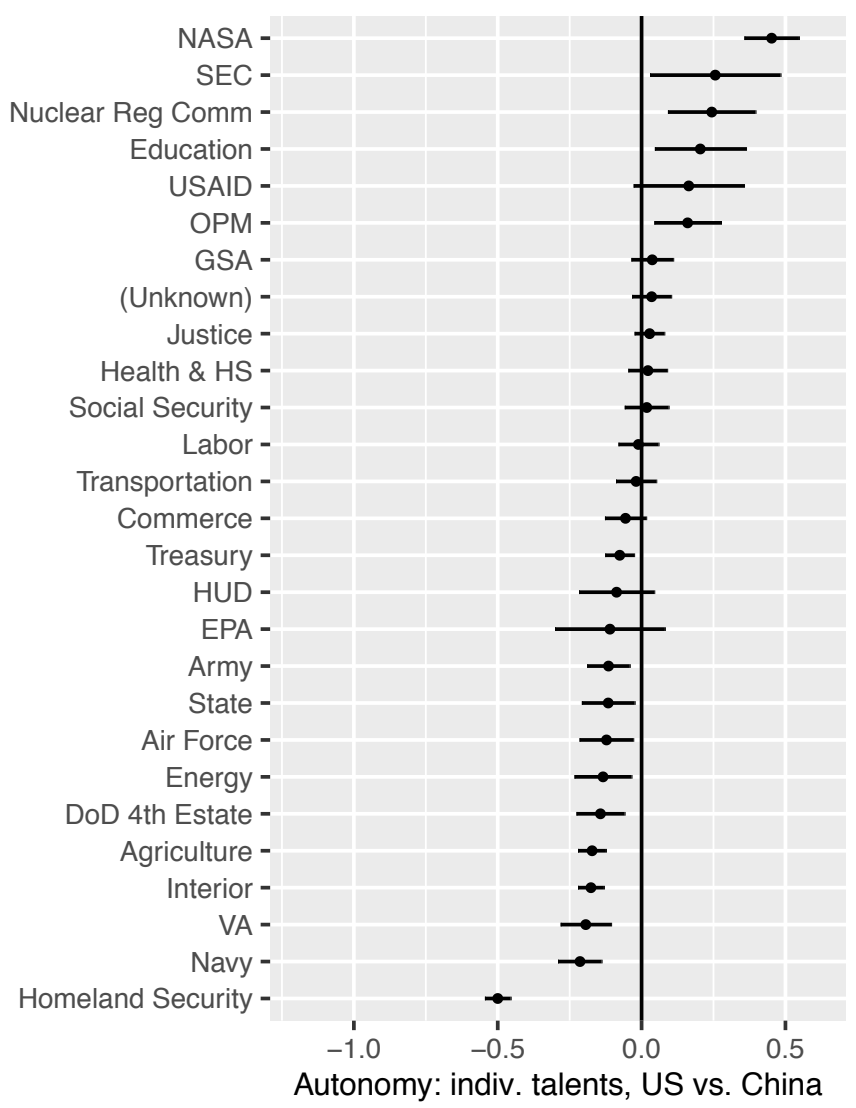

Figure B4: Innovation is rewarded (autonomy) in US Federal Agencies vs. China

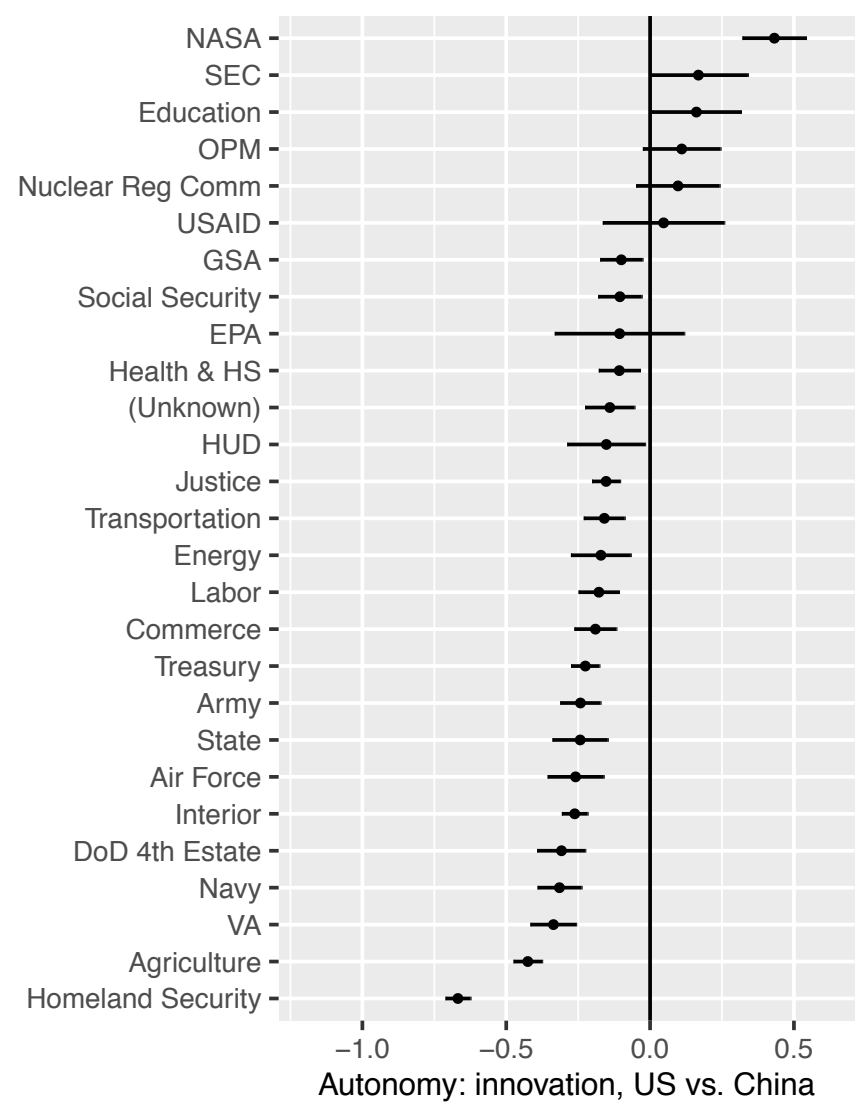


Figure B5 Robustness-Excluding High-Ranking Officials in China

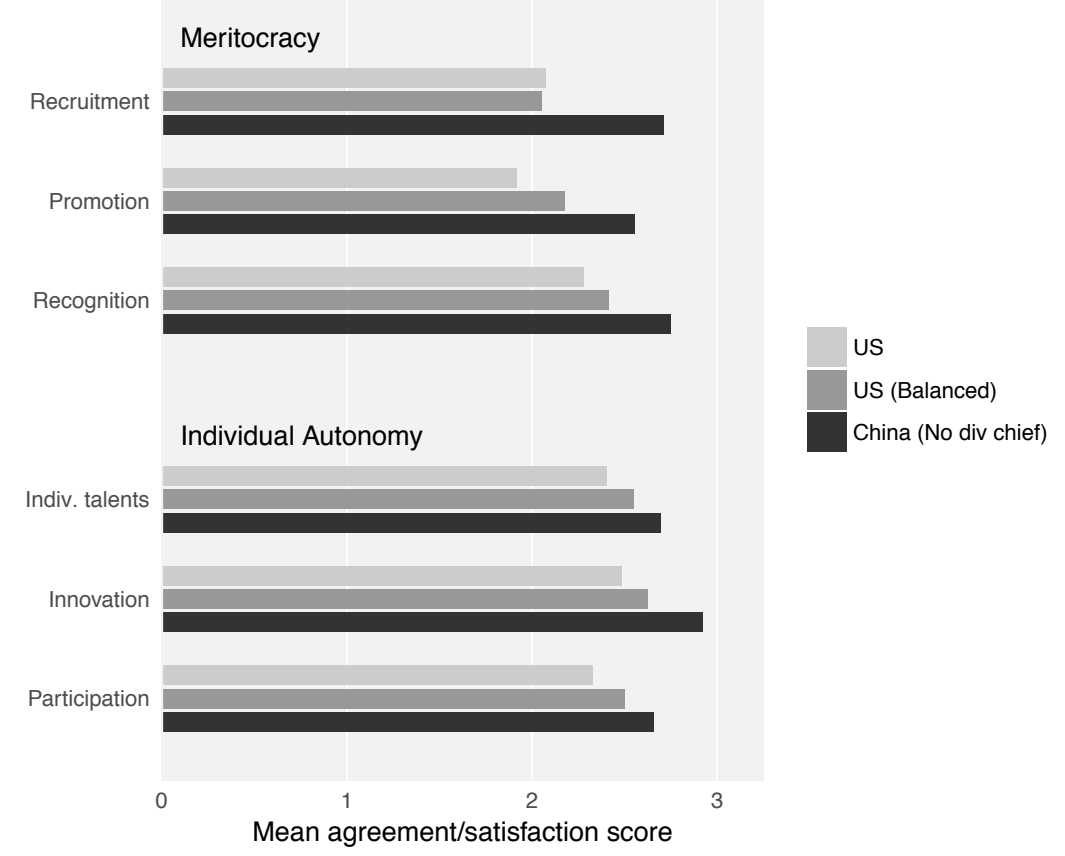

Notes. Mean responses from surveys of Chinese and U.S. (FedView) civil servants. Replication of Figure 3 after excluding all Chinese officials at and above the rank of vice-division chief (f $u$ chuji). China respondents in this subsample: $2,109$. 
Figure B6 Robustness-Excluding Communist Party Members

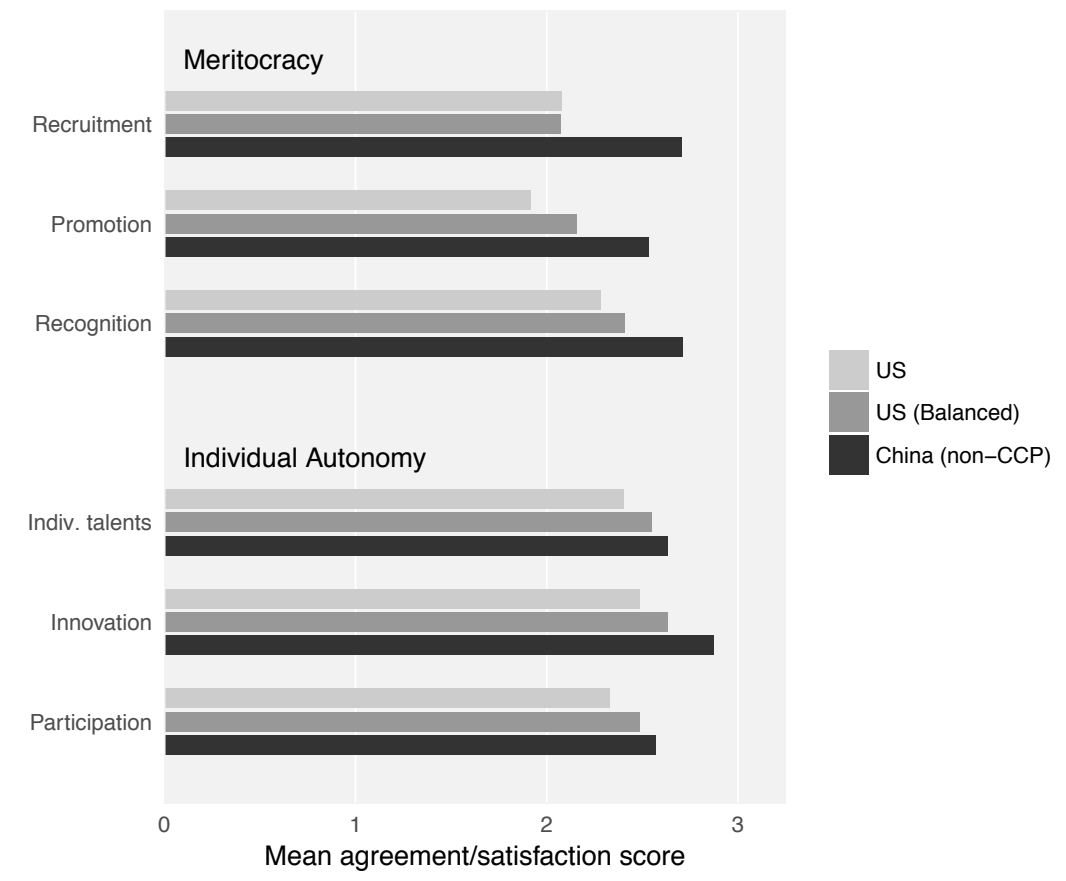

Notes. Mean responses from surveys of Chinese and U.S. (FedView) civil servants. Replication of Figure 3 after excluding all Chinese officials who are members of the Communist Party. China respondents in this subsample: 270 . 
Reassessing the Quality of Government in China

Online Supplement

Figure B7 Robustness - Only Officials Expressing Negative View on China's Reform

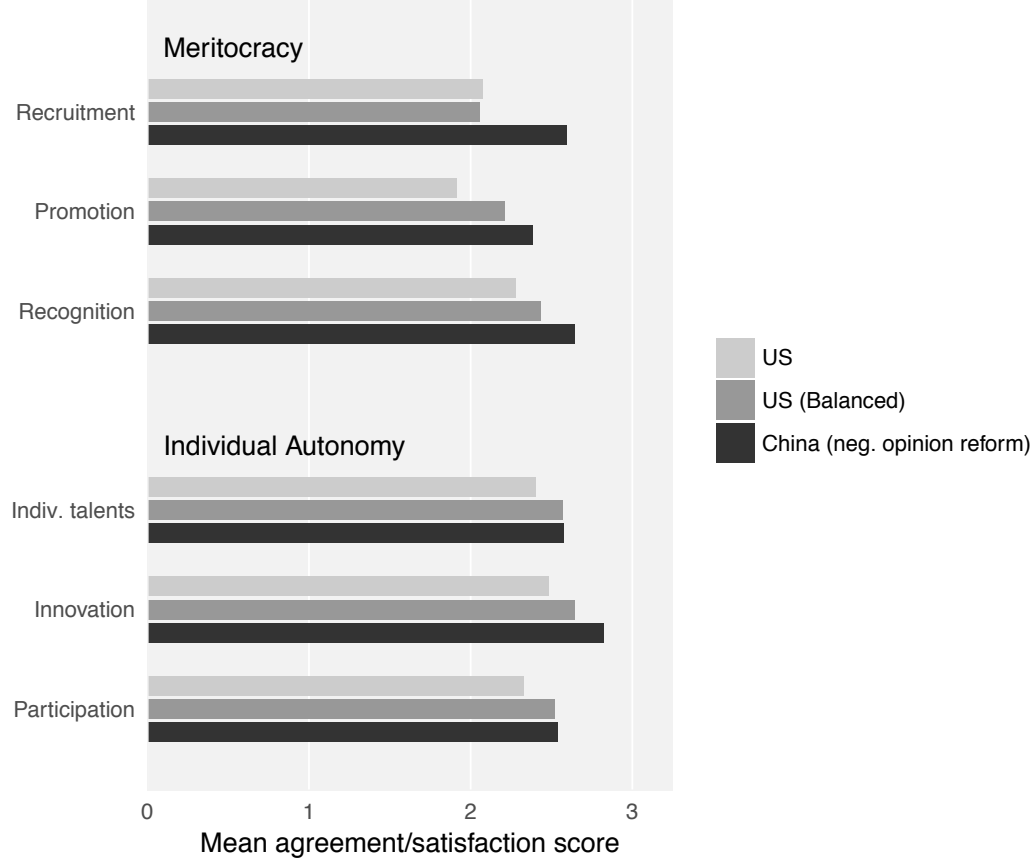

Notes. Mean responses from surveys of Chinese and U.S. (FedView) civil servants. Replication of Figure 3 examining only Chinese officials expressing the opinion that China's economic reform has not benefited the large majority of Chinese citizens. China respondents in this subsample: 1,127 . 